Quality-Assurance Plan for Groundwater Activities, U.S. Geological Survey Dakota Water Science Center
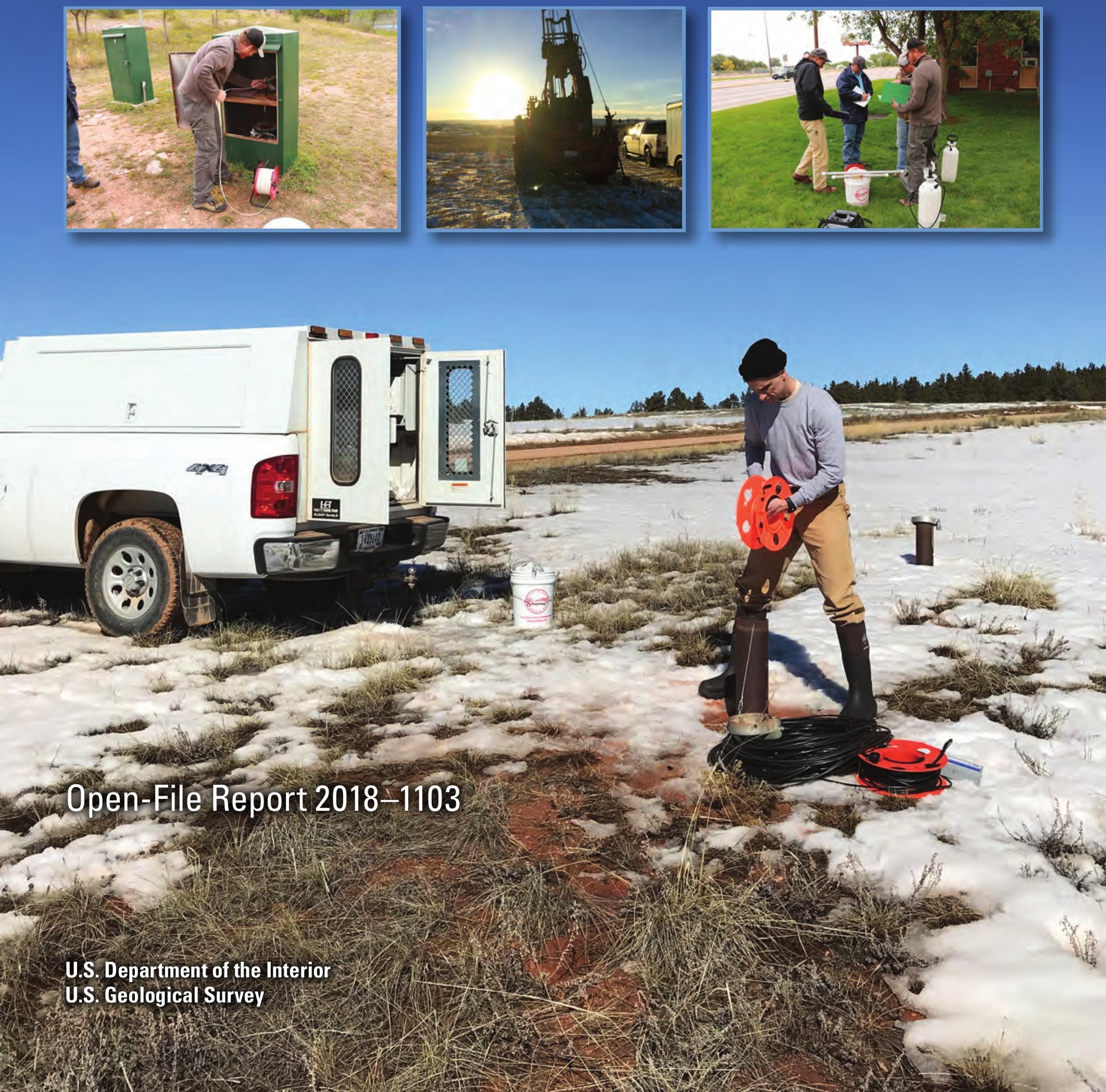
Cover. Upper left: U.S. Geological Survey (USGS) hydrologic technician measuring a groundwater level to monitor groundwater-level changes in the Madison aquifer near Rapid City, South Dakota (photograph by Galen Hoogestraat, USGS). Upper center: Drilling rig used to install monitoring wells near Rapid City, South Dakota, to be used for sampling and monitoring groundwater-level changes (photograph by Joshua Valder, USGS). Upper right: USGS staff prepare to slug a well to assess the hydrologic connection with the aquifer and to estimate hydrologic properties for the aquifer at the monitoring well site in Rapid City, South Dakota (photograph by Galen Hoogestraat, USGS). Background: USGS groundwater hydrologist lowers a transducer into an observation well near Jewel Cave National Monument in South Dakota to monitor groundwater-level changes in the Madison aquifer (photograph by Joshua Valder, USGS). 


\section{Quality-Assurance Plan for Groundwater Activities, U.S. Geological Survey Dakota Water Science Center}

By Joshua F. Valder, Janet M. Carter, Steve M. Robinson, Chris D. Laveau, and Joel A. Petersen

Open-File Report 2018-1103 


\section{U.S. Department of the Interior \\ RYAN K. ZINKE, Secretary}

\section{U.S. Geological Survey James F. Reilly II, Director}

\section{U.S. Geological Survey, Reston, Virginia: 2018}

For more information on the USGS - the Federal source for science about the Earth, its natural and living resources, natural hazards, and the environment-visit https://www.usgs.gov or call 1-888-ASK-USGS.

For an overview of USGS information products, including maps, imagery, and publications, visit https://store.usgs.gov.

Any use of trade, firm, or product names is for descriptive purposes only and does not imply endorsement by the U.S. Government.

Although this information product, for the most part, is in the public domain, it also may contain copyrighted materials as noted in the text. Permission to reproduce copyrighted items must be secured from the copyright owner.

Suggested citation:

Valder, J.F., Carter, J.M., Robinson, S.M., Laveau, C.D., and Petersen, J.A., 2018, Quality-assurance plan for groundwater activities, U.S. Geological Survey Dakota Water Science Center: U.S. Geological Survey Open-File Report 2018-1103, 28 p., https://doi.org/10.3133/ofr20181103. 


\section{Contents}

Abstract

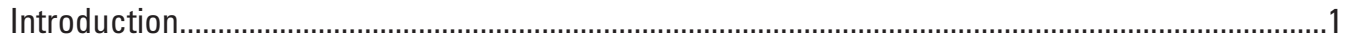

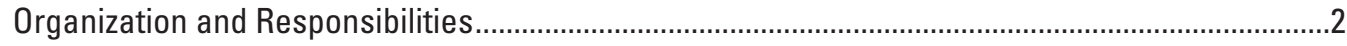

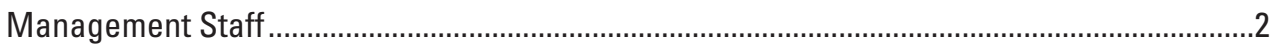

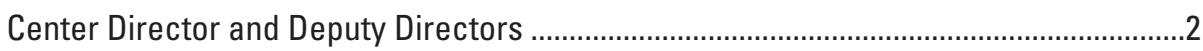

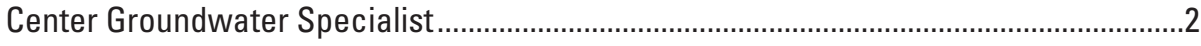

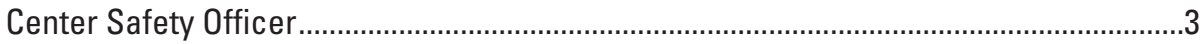

Center Groundwater Database Administrators .................................................................3

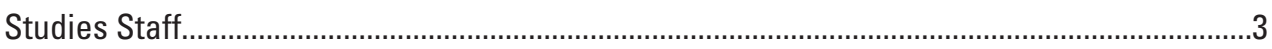

Center Section Leads/Studies Chiefs ..........................................................................

Center Groundwater Project Chiefs .................................................................................

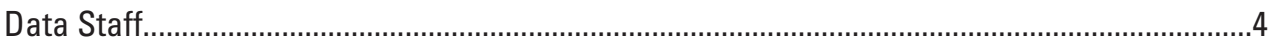

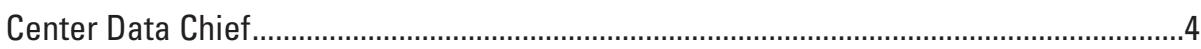

Data Program Field Office Chiefs .................................................................................

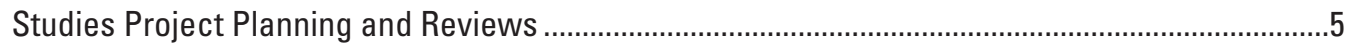

Development of Project Proposals .......................................................................................

Development of Work Plans....................................................................................................

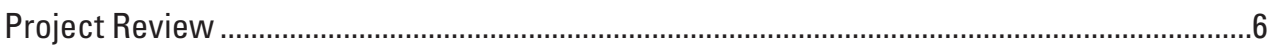

Triennial Discipline Reviews ............................................................................................

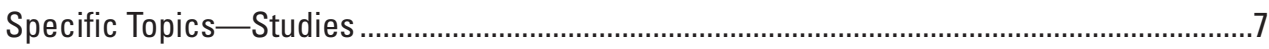

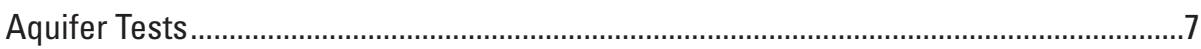

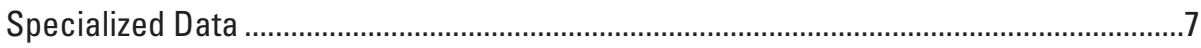

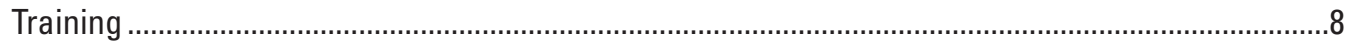

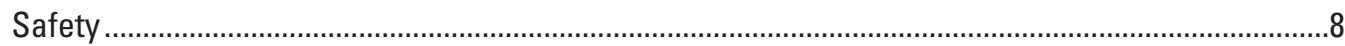

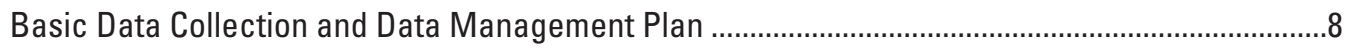

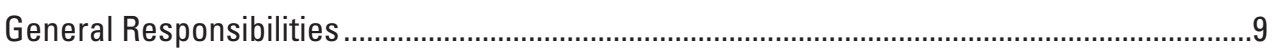

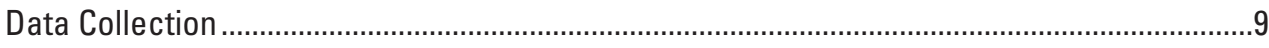

Documentation of Routine Technical Procedures ..........................................................9

Instrumentation and Calibration......................................................................................

Field Files for Observation Wells...................................................................................

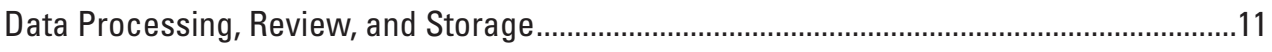

Continuous Recording Groundwater Wells..................................................................11

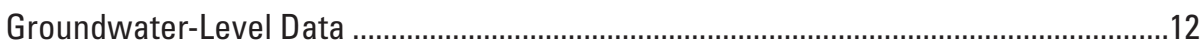

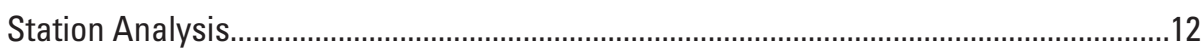

Manuscript and Annual Report ...............................................................................12

Analyzed, Approved, and Audited Records................................................................12

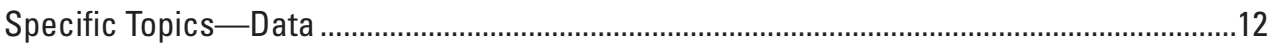

Documentation of Non-Routine Activities....................................................................12

Identification and Control of Samples Collected During Well Installation.......................13

Winterizing Pressure Head Wells ....................................................................................

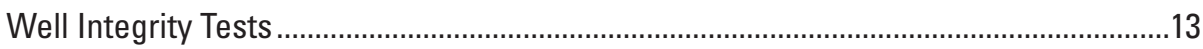

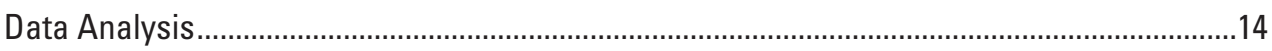

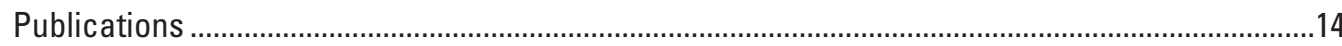




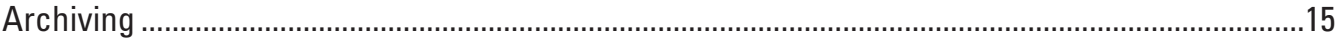

Summary

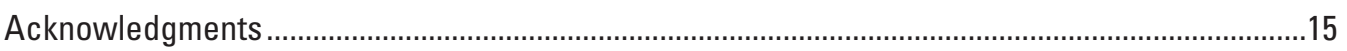

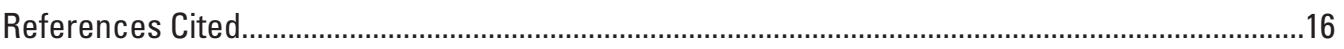

Appendix 1. Groundwater Technical Memorandums, Groundwater Technical Notes,

Water Resources Policies, and the U.S. Geological Survey Survey Manual.......................20

Appendix 2. Groundwater Site Inventory (GWSI) Coding Forms...................................................

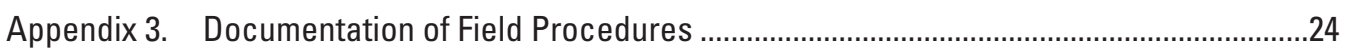

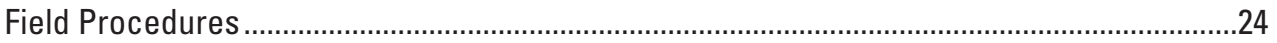

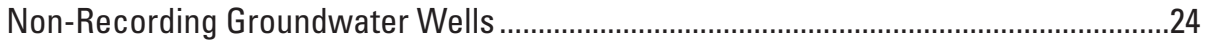

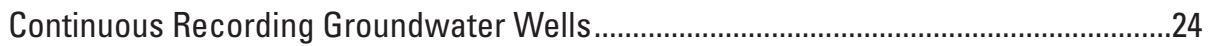

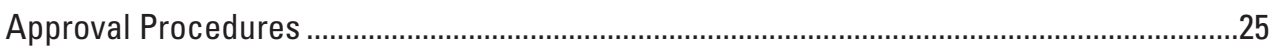

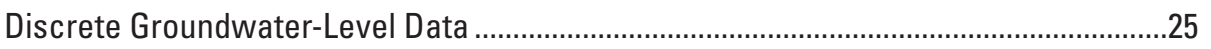

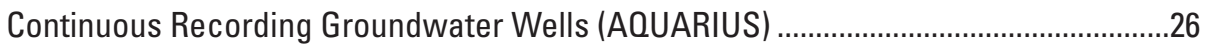

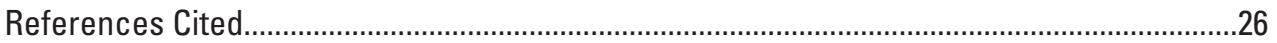

Appendix 4. Dakota Water Science Center Groundwater Archive Plan.........................................27

Groundwater Flow and Transport Models.........................................................................27

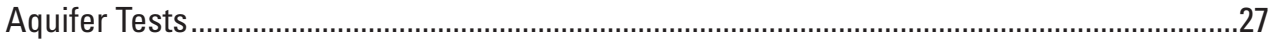

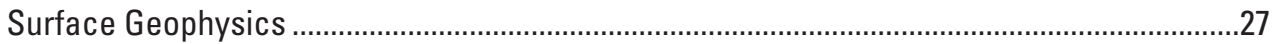

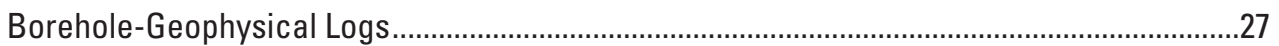

National Water Information System Data.....................................................................2

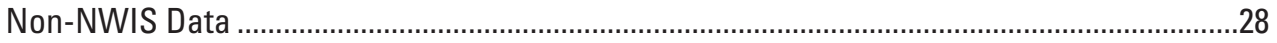

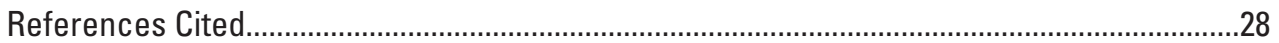

\section{Tables}

1. Dakota Water Science Center project review form elements.........................................6 


\section{Conversion Factors}

U.S. customary units to International System of Units

\begin{tabular}{ccc}
\hline Multiply & By & To obtain \\
\hline & Length & \\
\hline foot $(\mathrm{ft})$ & 0.3048 & meter $(\mathrm{m})$ \\
\hline
\end{tabular}

\section{Supplemental Information}

Water year (WY) is the 12-month period, 0ctober 1 through September 30, and is designated by calendar year in which it ends.

\section{Abbreviations}

$\begin{array}{ll}\text { CRN } & \text { Climate Response Network } \\ \text { DOI } & \text { Department of Interior } \\ \text { DWSC } & \text { Dakota Water Science Center } \\ \text { FSP } & \text { Fundamental Science Practices } \\ \text { GWQAP } & \text { Groundwater Quality-Assurance Plan } \\ \text { GWSI } & \text { Groundwater Site Inventory } \\ \text { HIF } & \text { Hydrologic Instrumentation Facility } \\ \text { NWIS } & \text { National Water Information System } \\ \text { OAP } & \text { quality-assurance plan } \\ \text { RMS } & \text { Records Management System } \\ \text { USGS } & \text { U.S. Geological Survey }\end{array}$





\title{
Quality-Assurance Plan for Groundwater Activities, U.S. Geological Survey Dakota Water Science Center
}

\author{
By Joshua F. Valder, Janet M. Carter, Steve M. Robinson, Chris D. Laveau, and Joel A. Petersen
}

\section{Abstract}

As the Nation's principal earth-science information agency, the U.S. Geological Survey (USGS) is depended upon to collect accurate data and produce factual and impartial interpretive reports. Methods for data collection and analysis that were developed by the USGS have become standard techniques used by numerous Federal, State, and local agencies and by private enterprises. The USGS has implemented a program designed to ensure that all scientific work done by or for USGS Water Science Centers is done in accordance with a quality-assurance plan. The implementation of a groundwater quality-assurance plan will enhance groundwater data collected by the USGS. This report is a quality-assurance plan for groundwater activities conducted by the USGS Dakota Water Science Center and is meant to complement qualityassurance plans for surface-water and water-quality activities and similar plans for the Dakota Water Science Center and general project activities throughout the USGS.

\section{Introduction}

The U.S. Geological Survey (USGS) performs a variety of groundwater data-collection programs and investigations to assess the status of the Nation's groundwater resources. Results of these activities are used to aid the citizens of the United States in developing, managing, and maintaining its groundwater resources. As the Nation's principal earth-science information agency, the USGS is depended upon to collect accurate data and produce factual and impartial interpretive reports. The USGS has developed various techniques and methods for field-based data collection that have become the standard techniques used by numerous Federal, State, and local agencies (Kozar and Kahle, 2013). Recently, as electronic data have become more accessible, having standard field methods in data collection has become increasingly important because the USGS data that are being collected are used by other scientific organizations and by the public to address questions of natural-resource and environmental problems. Many of these problems are addressed through an open, public process. As a result, the data collected by scientific organizations, such as the USGS, are being scrutinized for objective evidence, regardless of the organizations' reputation and historical credibility (Kozar and Kahle, 2013).

To address these demands and expectations, the USGS has implemented a program designed to ensure that all scientific work done by or for USGS Water Science Centers is conducted in accordance with a quality-assurance plan (QAP). The USGS Office of Quality Assurance has the responsibility to develop, coordinate, and implement the quality-assurance program for groundwater activities performed by USGS Water Science Centers. As part of that program, the USGS has directed the preparation of a Groundwater Quality-Assurance Plan (GWQAP), which covers all groundwater activities by USGS Water Science Centers. Schroder and Shampine (1992) and Shampine and others (1992) outline the guidelines for preparing QAPs for individual USGS Water Science Centers and integrating the quality assurance into project work plans. Guidelines presented in this report are intended to supplement Schroder and Shampine (1992), Shampine and others (1992), and Brunett and others (1997) to provide more specific details related to the USGS Dakota Water Science Center's (DWSC's) groundwater activities.

As summarized in Kozar and Kahle (2013, p. 2), a QAP can be defined as, "a formal document that describes the management policies, objectives, principles, organizational authority, responsibilities, accountability, and implementation plan of a responsible organizational unit or group for ensuring quality in its products." The implementation of a groundwater QAP will enhance the groundwater data collected by the USGS by providing consistency, accountability, comparability, traceability, and repeatability (Kozar and Kahle, 2013).

This report is a QAP for groundwater activities conducted by the DWSC and is meant to complement QAPs for surfacewater and water-quality activities and similar plans for the DWSC and general project activities throughout the USGS. Included within these practices are the assignment of responsibilities for implementing quality-assurance activities in the DWSC and establishment of review procedures needed to ensure the technical quality and reliability of the groundwater products. This report presents quality-assurance policies pertaining to the collection, processing, analysis, storage, review, and publication of groundwater data. In addition, policies related to organizational responsibilities, training, and 
project planning are presented. Groundwater activities include all tasks pertaining to data-collection programs, interpretive and research projects, and data management. Additional groundwater technical field procedures used by USGS technicians and hydrologists that are not described in this document are available in Cunningham and Schalk (2011).

\section{Organization and Responsibilities}

Although quality assurance is a personal responsibility of all employees of the USGS, ultimate quality-assurance responsibility within each Water Science Center lies with the Water Science Center Director. Clear statements of specific responsibilities promote an understanding of each person's role in the overall process of quality assurance and can help to prevent errors and deficiencies that may otherwise occur. Even if quality-assurance responsibilities are ancillary duties for some employees, these functions are to be documented.

The following is a list of DWSC personnel responsible for implementing the GWQAP for groundwater activities.

Management

1. Center Director and Deputy Directors

2. Center Groundwater Specialist

3. Center Safety Officer

4. Center Groundwater Database Administrators

Studies

1. Center Section Leads/Studies Chiefs

2. Center Groundwater Project Chiefs

Data Section

1. Center Data Chief

2. Data Program Field Office Chiefs

\section{Management Staff}

The management staff are responsible for implementing the policies and procedures as requested by USGS headquarters to ensure national consistency among the data and studies, collection, interpretation, and publishing of information. The management staff include the Center Director and Deputy Directors, the Center Groundwater Specialist, the Center Safety Officer, and the Center Groundwater Database Administrators. A more detailed description of each of the roles are provided in this section.

\section{Center Director and Deputy Directors}

The DWSC's Center Director and Deputy Directors are responsible for the following:

1. Managing and directing the DWSC program, including all groundwater activities.

2. Ensuring that groundwater activities in the DWSC meet the needs of cooperating agencies, including State and local agencies, the general public, and the Federal Government.

3. Ensuring that all aspects of the GWQAP are understood and followed by DWSC personnel.

4. Providing final resolution of any conflicts or disputes related to groundwater activities within the DWSC.

5. Ensuring that the DWSC staff execute the procedural and technical communications that come from Region and Headquarters.

6. Ensuring that technical reviews of all groundwater activities are conducted.

7. Ensuring that all publications and other technical communications released by the DWSC are accurate and in accord with USGS policies.

8. Ensuring that groundwater training is incorporated into each employee's training plan, where appropriate.

\section{Center Groundwater Specialist}

The DWSC's Groundwater Specialist is responsible for the following:

1. Maintaining current groundwater technical expertise for the DWSC.

2. Assisting project personnel with preparation of groundwater technical matters.

3. Participating in technical reviews of groundwater activities.

4. Reviewing groundwater-related project proposals.

5. Reviewing groundwater-related products.

6. Providing information, technical memorandums (appendix 1), and consultation to the DWSC staff on groundwater technical matters.

7. Communicating with the Center Section Leads, Center Groundwater Project staff, and Data Program Field Office Chiefs/Studies Chiefs on needed or required technical procedures. 
8. Maintaining the DWSC archive of required routine technical procedures.

9. Maintaining the geophysics, aquifer test, and model archives.

10. Providing technical assistance and guidance for data entry and network review and approval.

11. Maintaining the groundwater technical-procedure documents file.

\section{Center Safety Officer}

The DWSC's safety officer is responsible for the following:

1. Reviewing proposed groundwater project's Job Hazard Analysis to ensure they follow all required safety policies and programs. Ensuring that policies and guidelines for work activities follow recommended safety rules and regulations covered in the USGS Safety Manual (U.S. Geological Survey, 2001) and related safety publications.

2. Encouraging an attitude of safety awareness in DWSC employees for activities on and off the job.

3. Assisting and advising supervisory personnel in job safety analysis and job safety training.

4. Ensuring that required safety training is conducted on schedule.

5. Conducting annual safety inspections and assisting personnel in conducting work site inspections when necessary.

\section{Center Groundwater Database Administrators}

The DWSC's groundwater Database Administrators are responsible for the following:

1. Managing databases to ensure data integrity, system security, and user accessibility.

2. Conducting adequate backup and recovery procedures that follow agency guidelines.

3. Maintaining the databases and correcting problems in a timely manner to minimize loss of data and user access time.

4. Uploading and downloading data from national database repositories at recommended intervals.

5. Overseeing system security by controlling system access, assigning user identification, and following agency guidelines on computer system security.
6. Ensuring that site files are populated for each site in the system and not duplicated in the database.

7. Working with the Center Groundwater Specialist and project staff to ensure proper documentation and timely data entry into the groundwater site inventory database.

8. Working with the Center Groundwater Specialist to ensure all project staff are properly trained in using the Groundwater Site Inventory (GWSI) database, such as site creation and data entry.

\section{Studies Staff}

The studies staff are responsible for conducting interpretive investigations in accordance with the policies and procedures implemented by the management staff to ensure that the highest quality products are made publicly available. The studies staff include the Center Section Leads/Studies Chiefs and the Center Groundwater Project Chiefs. A more detailed description of each of the roles is provided in this section.

\section{Center Section Leads/Studies Chiefs}

The DWSC's Groundwater Section Lead is responsible for the following:

1. Ensuring that all aspects of this QAP are understood and followed by DWSC personnel.

2. Managing and directing groundwater activities assigned to the section and ensuring that the stated objectives are met in a timely manner.

3. Reviewing the work plans for groundwater programs and projects.

4. Keeping DWSC staff briefed on procedural and technical communications from Region and Headquarters.

5. Providing the project chief with technical and administrative support as needed.

6. Creating and periodically updating, with groundwater personnel in the section, a training plan for each employee, where appropriate.

7. Ensuring that project activities are carried out in a timely manner.

8. Reviewing groundwater reports under his or her direction.

9. Monitoring progress of groundwater project chiefs in implementing the GWQAP for their respective projects. 


\section{Center Groundwater Project Chiefs}

The DWSC's groundwater Project Chiefs are responsible for the following:

1. Directing and conducting the technical work of the project, including all phases of data collection, data review, data storage, data analysis, and report preparation according to appropriate procedures.

2. Communicating project plans, progress, and problems to supervisors by providing written progress reports at periodic reviews.

3. Preparing written work plans, documenting project activities, preparing project-specific data management plans (U.S. Geological Survey, 2018a), and ensuring that data are placed in the USGS National Water Information System (NWIS) database or other repository, such as ScienceBase, as appropriate and in accordance with Fundamental Science Practices (FSP) data management plan requirements (U.S. Geological Survey, 2017a), prior to project termination.

4. Maintaining a project file containing memoranda, personal communications, technical-procedure documents used, original data, and other documentation.

5. Ensuring that project activities are carried out in a timely manner.

6. Creating an individual development plan with supervisor input.

7. Archiving of project files at the completion of the project.

\section{Data Staff}

The data staff are responsible for collecting and publishing high quality data in a nationally systematic approach, implementing all policies and procedures that are required by the management staff to ensure that all data collected will be aggregated into a publicly available national database. The data staff include the Center Data Chief and the Data Program Field Office Chiefs. A more detailed description of each of the roles are provided in this section.

\section{Center Data Chief}

The DWSC's Data Chief is responsible for the following:

1. Ensuring that all aspects of this QAP are understood and followed by DWSC personnel.

2. Managing and directing groundwater activities assigned to the data section and ensuring that the stated objectives are met in a timely manner.

3. Reviewing the work plans for groundwater programs and projects.

4. Keeping DWSC data section staff briefed on procedural and technical communications from USGS Region and Headquarters.

5. Providing the Data Program Field Office Chief with technical and administrative support as needed.

6. Creating an individual development plan for each employee engaged in groundwater data-collection activities, with input from Data Program Field Office Chiefs.

7. Ensuring that data section project activities are carried out in a timely manner.

8. Reviewing groundwater reports under his or her direction.

9. Monitoring progress of Field Office Chiefs in implementing the GWQAP for their respective projects.

\section{Data Program Field Office Chiefs}

The DWSC's Data Program Field Office Chiefs are responsible for the following:

1. Directing and conducting the work of the Field Office including all phases of data collection, data review, data storage, data analysis, and providing data to the public according to appropriate procedures.

2. Preparing analysis of work progress and documenting activities for groundwater data-collection projects.

3. Communicating Field Office groundwater work plans, progress, and problems by providing written or oral reports to the Data Chief.

4. Ensuring that data collected within the section are placed in the USGS NWIS database.

5. Maintaining required electronic files containing analysis of data, accurate descriptions of sites and equipment, and other documentation of field- or office-related work efforts.

6. Archiving of groundwater data electronic or paper files at the completion of the project or water year. 


\section{Studies Project Planning and Reviews}

The DWSC routinely conducts technical groundwater projects and data-collection programs. The success of these activities is dependent on a careful, deliberate, and systematic planning process. Quality-assurance requirements and a data management plan should be integrated into the project proposal, if one is required for the groundwater activity. Whether a groundwater program or project requires a separate QAP should be evaluated based on the complexity of the work, the needs of the DWSC or cooperator, or other criteria as described by Shampine and others (1992).

\section{Development of Project Proposals}

The DWSC has a policy that provides guidelines for the development and review of proposals. Additional guidance is provided in the most recent guidance from the USGS, Water Mission Area Memorandum 2013.01 (U.S. Geological Survey, 2012a), which provides guidance for the development and review of project proposals. Mandatory elements for project proposals are provided within this GWQAP to guide the preparation and transmittal of project proposals.

All project work performed by DWSC staff should have a project proposal that is reviewed and approved within the Center, by the Director and Administrative Officer, and, if applicable, submitted to the National Proposal Repository for an additional USGS headquarters review before any work is performed. The development and the routing of the proposal is described in the following section.

Proposal authors will draft project proposals along a spectrum ranging from pre-proposals (informal, ideas/ concepts) to full proposals, depending on factors such as level of concept development, initial discussion of concepts with potential funding partners, and likelihood of funding. A budget also needs to be developed for each proposal using the DWSC budget spreadsheet provided by the Administrative Officer.

Once the first draft of the proposal is written, the DWSC proposal routing and review process starts with the proposal author's supervisor. After the supervisor has provided input and approved the proposal, then the proposal and budget spreadsheet will be routed for approval to the following:

1. Center Collateral Duty Environmental Protection Coordinator

2. Center Discipline Specialist (such as the Groundwater Specialist) and others as appropriate (such as Report Specialist and Data Chief)

\section{Center Safety Officer}

4. Center management team (Deputy Directors, Director, and Administrative Officer)

Proposals should not be shared with any person outside the DWSC until the proposal has been vetted by the Center's management team and the appropriate discipline specialist(s). If there are any significant changes (for example, added tasks or funding changes) after the proposal has been vetted, the proposal will undergo a second review by the management team and Center specialists.

Allowing sufficient time for the review process is necessary to allow adequate time for review and comment by the management team and Center specialists. The recommended timing will be to allow for 3 business days for responses from the management team and Center specialists. In special circumstances, time-sensitive deadlines may be necessary to receive comments from the management team/specialists. In these special cases, it is recommended to communicate with the management team and Center specialists early so that accommodations can be made to meet the short turnaround. The last step in the proposal process, prior to the investigative study beginning, is to submit proposals that utilize cooperative matching funds for interpretive work to the National Proposal Repository (appendix 1; Water Mission Area Memorandum 2013.01; U.S. Geological Survey, 2012a).

\section{Development of Work Plans}

A work plan shall be developed for every groundwater program or project. The work plan can be a part of the proposal or a stand-alone document. The complexity of the program or project will determine the detail of the work plan. The project proposal may satisfy the requirement of a work plan where groundwater activities are routine or highly standardized. Typically, the work plan that is included with the proposal does not include all the necessary elements. The work plan should include, as appropriate, data-collection, management, and storage plans; equipment and instrumentation needs; data-analysis techniques; report or final product plans; cost estimates; time schedules; availability of personnel; training needs; and other elements, as necessary. The groundwater Project Chief is responsible for documenting work plan elements not included in the proposal. An element frequently overlooked is budgeting time and personnel needed for proper archiving of data and interpretations. Without appropriate project planning (Green, 1991) and the documentation of individual project tasks, quality objectives and project deadlines may not be reasonably known. Initial project/program planning can be guided by a detailed work plan; continued planning can be guided by periodic reviews.

To quality assure work plans, the following steps shall be performed by the DWSC. Work plans for programs with groundwater activities should clearly state that the GWQAP will be implemented and if there is the need to deviate from the GWQAP, these methods and deviations are highlighted within the project work plan. To the extent practicable, work plans should state data-quality objectives and describe the strategies to collect data to meet the intended use. When developing data-quality objectives, broader network needs should be considered as well as immediate objectives. Data-quality 
objectives are those qualitative and quantitative statements developed by data users to specify the quality of data needed from a particular data-collection activity. For example, to describe land subsidence in an area, groundwater levels need to be measured using a particular method, at a particular frequency, and to a particular accuracy. The work plan shall specify the means for cataloging and archiving all groundwater activities and files according to USGS policy.

Development of a work plan might also include the following:

1. A bibliographic search of available reports, articles, data, and other pertinent information.

2. Retrieval of relevant data from existing databases to determine the availability of and the need for additional data.

3. Review of other USGS file (paper) data, such as field canvass sheets, groundwater-level records, geophysical logs, lithologic logs, water-quality laboratory analytical sheets, or other original data.

Errors or inconsistencies in the database should be identified and corrected at this time.

\section{Project Review}

Project reviews are conducted quarterly by DWSC senior staff and project chiefs, along with select management staff, technical advisors, or discipline specialists as appropriate to ensure that project objectives are being met and to evaluate implementation of the GWQAP. Project reviews are used to maintain consistency in data collection, data analysis, and reporting. Regularly planned reviews shall ensure that the groundwater program or project is implemented and performed in a manner that results in a quality product done efficiently.

In general, the review ensures that the project begins properly, that no major technical item is overlooked in the planning, and that the objectives can be accomplished with the proposed approach. A topical outline and initial report writing should begin at an early stage. An annotated report outline, including draft illustrations, and a base map should be completed to ensure that report preparation and data collection and interpretation are coordinated. Problems in achieving project objectives should be identified as early as possible. The reviews should ensure that adequate data have been collected to meet the objectives and that the data-analysis process is on schedule and is yielding expected or reasonable results.

Data analysis procedures will be reviewed by the DWSC Groundwater Specialist as requested by the management team as part of the quarterly reviews for projects that include a groundwater component. Proposed projects and fully developed proposals also will be reviewed by the DWSC Groundwater Specialist (or their designee) for technical feasibility, training needs, and availability of related technical support within the USGS. When new or experimental methods are proposed, a technical-procedures notebook will be developed with the assistance of the Groundwater Specialist.

The DWSC uses either a standard form or a quarterly report out of the USGS's financial system (BASIS+) for documenting project reviews along with a spreadsheet for tracking action items that collectively provide an organized format to ensure that objectives are being met. The quarterly review reports are saved by the groundwater Project Chief in an

Table 1. Dakota Water Science Center project review form elements.

\begin{tabular}{|l|l|}
\hline Fiscal Year and Quarter - Month, Year & Date of Form Completion: \\
\hline Project Chief Name: & Associated Project Chiefs/Task Leaders: \\
\hline Project Name: & Project Number: \\
\hline Associated Accounts: & \\
\hline Status of work efforts and progress of the previous quarter: & \\
\hline Any issues preventing sufficient progress (for example, staffing, contracting): \\
\hline Overall status of products: \\
\hline Further action/next steps (for example, future progress): \\
\hline Additional notes:
\end{tabular}


archived area specified by the DWSC's Information Technology specialists. The elements of the review form or quarterly report are listed in table 1.

\section{Triennial Discipline Reviews}

The Office of Quality Assurance will manage periodic technical reviews of all Center programs. These reviews will consist of (1) observing field data-collection activities, (2) reviewing office documentation, (3) reviewing database contents, and (4) reviewing groundwater project progress and challenges. The following quality-assurance activities shall be performed by the USGS Office of Quality Assurance:

1. Review compliance with the requirements documented in the DWSC GWQAP. Reviews apply to all groundwater field and office activities. The technical review plan identifies the activities to be reviewed, scope of the review, requirements governing the review, organizations to be notified (if any), applicable documents, and tentative review schedule. The review shall, as a minimum, address the following questions:

a. Do training plans, work plans, technical-procedure documents, calibration records, and maintenance $\operatorname{logs}$ exist; are they complete; and are the plans and technical-procedure documents being implemented?

b. Do data management and archiving plans exist, are they complete and up-to-date, and are they being implemented?

c. Are project reviews being performed and documented according to the GWQAP?

2. Document all comments and recommendations in a formal technical review report.

3. Send all comments and recommendations to Headquarters and the Center Director. The Center Director is responsible for ensuring that all recommendations receive appropriate responses. The Office of Quality Assurance will receive copies of all correspondence between the DWSC's and Headquarters Groundwater Specialists relating to reviews and review plans.

\section{Specific Topics-Studies}

Past groundwater reviews of the DWSC have recommended that specific topics are addressed for the planning and implementation of interpretive study work performed by the DWSC groundwater project staff. The purpose of this specific topics section is to ensure that studies from unique hydrologic experiments are readily available and that supporting information is organized and accessible for future interpretations. Additionally, this section will address specific data management and compliance with Federal mandates regarding an open data policy (Executive Office of the President, 2013; memorandum M-13-13).

\section{Aquifer Tests}

Aquifer tests and other non-routine activities should follow the procedures described in Stallman (1971). Aquifer tests involve substantial efforts in time and interpretation. Conceptual understanding of complex aquifer systems often evolves with additional studies, and the application of different analytical models may be appropriate. To re-evaluate these data, an examination of specific details describing the data collection is often necessary. To facilitate the long-term accessibility of this information, the DWSC has implemented a central filing system and electronic archive to store and organize appropriate notes, explanations, and supporting data for aquifer tests.

The groundwater archive plan for the DWSC provides general description of the information that should be included. File locations will be established in offices (field and main office locations) to store information for studies supervised by the respective offices. The files will be maintained by the DWSC Groundwater Specialist and groundwater Project Chiefs or designee(s). Guidelines and policies that describe the preparation, approval, and archiving of aquifer-test results are described in the USGS technical memorandum 2009.01 (U.S. Geological Survey, 2009a). After the conclusion of the aquifer test, an archive will be established to accommodate the open data policy, which states that all aquifer tests resulting in hydraulic properties must be documented either in the larger hydrogeologic report or in a separate agency, peer reviewed report with an associated data release for the aquifer test data.

\section{Specialized Data}

Long-term studies of complex aquifer systems often include the development of new interpretive techniques and an evolving conceptual model of the groundwater system. These studies frequently include unique data collection associated with research activities and re-evaluation and additional interpretation of previously collected data is important. Federal policy has implemented an open data policy in 2013 that describes the agencies responsibilities to promote openness in sharing federally collected and interpreted data as described in memorandum M-13-13 (Executive Office of the President, 2013).

Specific digital and hardcopy storage areas have been created by the Center's Information Technology specialists to manage this specialized groundwater data. Subdirectories can be established for specific activities. A hardcopy storage file for supporting information is located in the DWSC studies section. Archive formats have been established for some of these activities (appendix 1; technical memorandums 2016.02, 2015.02, 2010.01, 2009.02, 2009.01, and 2006.02; U.S.

Geological Survey, 2016a, 2015, 2010a, 2009b, 2009a, 2006) 
and are described in detail in the subsequent sections of this report. The DWSC Groundwater Specialist will periodically update these guidelines as new groundwater study techniques are utilized and data-collection procedures are revised.

The DWSC has extensive involvement in projects that study groundwater flow in aquifers. Several of these projects have included unique groundwater tracer experiments designed to develop a better understanding of groundwater flow in complex fractured and karstic aquifers. Collaborative efforts with other Water Science Centers, research scientists, and local hydrologists have highlighted the need to have wellmanaged data that are readily accessible in digital formats with organized supporting hardcopy information. A subdirectory has been established in the digital archives so that these data will be permanently documented and available in the future. A hardcopy storage file for supporting information is located in the DWSC studies section. Lastly, in accordance with the 2013 open data policy (Executive Office of the President, 2013, memorandum M-13-13), all groundwater data collected, including routine data such as groundwater levels, or specialized data including groundwater tracer data or any subminute aquifer test data collected, must be released to the public either through NWISWeb (U.S. Geological Survey, 2018b) or as a separate data release through an accepted repository such as ScienceBase. In most cases, all routine data collected will be released through NWISWeb and all specialized data will be released as a data release, which follows the guidance of the USGS FSP for release of scientific data (U.S. Geological Survey, 2018c).

\section{Training}

Employee training is an investment that has short-term and long-term benefits to DWSC groundwater activities. The immediate benefits permit confidence that the work is being performed correctly and accurately. The long-term benefits provide for technically competent employees that are of great value to the organization. Because all work in the scientific arena is receiving increased scrutiny, the qualifications of groundwater personnel relative to the technical demands of the work to be performed must be well documented.

Groundwater Project Chiefs prepare individual development plans annually that are reviewed by the Project Chief's supervisor. These individual development plans shall include the individual's short-term training needs, such as the knowledge and skills needed to perform currently assigned tasks, and long-term training needs, such as skills needed to perform future tasks and for career development. All training plans should be reviewed annually and updated according to the current and future groundwater program needs.

Appropriate training includes new employee training, USGS National Training Center courses, mentoring, on-thejob training, vendor-provided training, and academic courses.
Monthly USGS web sessions are encouraged for continued training for those that are working with groundwater data collection and the groundwater data program. A list of groundwater training resources is available at http://water.usgs.gov/ usgs/ogw/training.html.

Training for DWSC employees is currently facilitated though Department of Interior (DOI) Talent. Prior to DOI Talent, training records were maintained in the earlier Employee Development Needs Assessment system and in the DOI Learn system, which has been archived by the DWSC's Training Officer. Qualifications of cooperators (Federal, State, and local agencies) performing tasks shall be to the satisfaction of the groundwater Section Lead and the DWSC Director and Deputy Directors.

\section{Safety}

Safety is an important consideration in planning and executing groundwater work plans. As a component of all groundwater proposals and work plans, all job hazards should be identified to the extent possible and properly documented on the USGS job hazard analysis form. Each employee is responsible for reading memorandums and manuals, and attending specified training classes related to safety.

Incorporating safety issues when planning groundwater activities is an important step in preventing accidents. Also, ongoing attention to safety issues can have a positive effect on the quality of groundwater data because field personnel are prepared to deal with dangerous conditions that create distractions. The DWSC Director has designated individuals as Safety Contacts who can be consulted for guidance on safety planning, training, memorandums, and the completion of accident reports.

\section{Basic Data Collection and Data Management Plan}

All USGS studies must account for the data that will be collected. A data management plan will be created for each project during the proposal stage so that the disposition of the data collected as part of the study will be known before work begins (U.S. Geological Survey, 2018a). General responsibilities for basic data collection, management, and review in the DWSC are described in this section of the report. In addition, specific components of the groundwater data management are described including data collection; data processing, review, and storage; and data analysis. Specific topics also are described to ensure that data from non-traditional activities conducted in the DWSC will be readily available and that supporting information is organized and accessible. 


\section{General Responsibilities}

Well and spring information are recorded on forms 9-1904-A and 9-1904-B (appendix 2). These forms along with supporting information such as well completion reports (also known as driller's logs) are stored in either (1) file cabinets organized by county, township, range, and section number in various offices within the DWSC or (2) available at a national archive facility. Reviewing this information is the responsibility of the Center's Groundwater Specialist or designee (such as the groundwater Database Administrator). Prompt review of location information, site identification number, and selection of aquifer code is important to facilitate the proper entry of subsequent information in databases. An essential part of this review is to check for duplicate entries for the same well or spring that may exist in the database. Entry and retrieval of groundwater-level and water-quality data are often overlooked or misinterpreted if data are stored under more than one identifier.

Continuous groundwater-level records collected by data section technicians or studies hydrologists enter all data collected in the AQUARIUS database (technical memorandums 2017.03 [U.S. Geological Survey, 2017b] and 2017.04 [U.S. Geological Survey, 2017c]). The DWSC Data Chief or designee is responsible for reviewing the data records supporting information with assistance from technicians in the DWSC. The DWSC Groundwater Specialist is responsible for reviewing data correction techniques and other unique problems associated with working data records for individual wells and springs.

\section{Data Collection}

This section documents the technical procedures for routine and non-routine data-collection activities, instrumentation use, and identification and control of samples collected within the DWSC. Scientists and technicians that are collecting groundwater data must be familiar with the procedures specified in this plan. Specific field data-collection techniques and methods are documented in appendix 3 .

\section{Documentation of Routine Technical Procedures}

Written records of exactly how data are collected are critical to establishing the consistency, comparability, repeatability, and traceability of scientific data. The methods used to collect a specific dataset shall be documented, and the documentation shall be maintained with the data. For routine field activities, technical-procedure documents are a means of ensuring that detailed documentation is generated prior to data collection and shall be identified or prepared during the formal planning phase of the project, as applicable. A technicalprocedure document is a detailed description of a sequence of actions to be used to collect data to ensure repeatability of the work and comparability of results. If it is necessary to deviate from the technical-procedure documents when collecting data, then these deviations must be clearly described in the project records.

Technical-procedure documents for routine field data collection are available in Cunningham and Schalk (2011) or in the technical memorandum web links described in appendix 1 . The water-quality aspects of groundwater activities that are addressed in the QAP for water quality need not be duplicated. Technical-procedure documents for activities not covered by these routine activities shall be prepared and maintained in project files. When data-collection methods are new or experimental, a record of the conduct, progress, and results of these methods shall be maintained in procedure notes.

\section{Instrumentation and Calibration}

All instruments, devices, and equipment (including steel tapes) used to collect groundwater data are categorized as instruments. Because of the complexity of some instruments, their effect on the quality of the data may be unknown or unquantifiable. To ensure the consistency, comparability, and repeatability of collected data, instruments must be identified, calibrated, maintained, and operated in an appropriate manner. Calibration is the comparison of the output from an instrument to a standard or to the output from another instrument or procedure of known accuracy to detect, correlate, report, or eliminate by adjustment variations in the accuracy of the instrument being evaluated.

Instruments used to collect data shall be identified with a unique identifier on the field form. Calibration procedures and schedules shall be established for each instrument based on the stability characteristics of the instrument, required accuracy, intended use, manufacturer's recommendation, and other conditions that may affect the quality of the data. The calibration procedure and schedule should be documented in the data-collection files. Instruments shall be identified by type, manufacturer, and model. Calibration shall be performed whenever the accuracy of the instrument is suspect, regardless of the calibration schedule. Instruments consistently determined to be out-of-calibration shall be repaired or replaced.

An activity log will be maintained for each instrument requiring calibration. The log should contain all information pertinent to calibration, whether performed by DWSC staff or by an outside organization or vendor. Calibration documentation recorded in the log shall include the following:

1. Name of organization and individual performing the calibration.

2. Identification of the instrument by type, manufacturer, model, serial number, or other unique and permanent identifier.

3. Identification of calibration standard, including the range and accuracy. 
4. Identification of the document that describes the calibration process.

5. Date of current calibration and date or milestone for next scheduled calibration.

6. Records of instrument readings before and after any calibration.

Data collected with instruments determined to be out-ofcalibration shall be evaluated to determine the effect on the intended use of the data. Affected data shall be discarded or their limitations documented in the database and in any application of the data.

All instruments used to collect data shall be operated in accordance with the manufacturer's manual, unless otherwise documented. Modifications to the manufacturer's operating procedure shall be appended to the manufacturer's manual, which shall be kept with the equipment at all times. Digital versions of manuals for all instruments also shall be kept on file with the Data Program Field Office Chiefs. Operating procedures may be included in technical-procedure documents. Instrument maintenance shall be performed in accordance with the manufacturer's recommendations. A log shall be used to record maintenance performed.

In 2017, a formal technical memorandum (2017.09; appendix 1; U.S. Geological Survey, 2017d) was announced in which a process and schedule for a groundwater tape calibration program were established to improve upon the consistency of the electric and steel tapes being used for groundwater-level data collection. All steel tapes used for making groundwater-level measurements will be checked by the Hydrologic Instrument Facility (HIF) at least once every 6 years. All electric tapes used for making groundwater-level measurements will be checked by the HIF at least once every 2 years. Project activities can result in wear-and-tear of equipment. The steel and electric tapes should be inspected before use and, if warranted based on this inspection, submitted for an additional calibration check at the HIF.

As part of this calibration program, every groundwater tape used in the DWSC must be registered and tracked in a database maintained by the HIF. The DWSC will be notified by HIF when a tape is due for a calibration check based on the information in the database. The DWSC will send the tapes selected for a calibration check to the HIF, and the HIF will (1) visually inspect the tape for damage and (2) check each 100 -foot length interval of the tape against a National Institute of Standards and Technology traceable reference tape.

The offset due to the electric or steel tape will be measured and returned to the DWSC along with a calibration report. All steel and electric tapes in the DWSC will be identified with the following identification:

\section{$S S-A X X-N N N-T$}

where

$$
\begin{gathered}
S S=\begin{array}{c}
\text { the postal abbreviation for the State in which } \\
\text { the tape is located; } \\
\text { the location of the office in which the tape is } \\
\text { located; }
\end{array} \\
\begin{array}{c}
\text { number from } 1 \text { to } 99 \text {, starting with } 01 \text { and } \\
\text { increasing in order by } 1 \text { (new values are } \\
\text { assigned by the Center Data Chief); }
\end{array} \\
N N N=\quad \begin{array}{l}
\text { tape length, in feet; and } \\
\text { type of tape (S for steel and } \mathrm{E} \text { for electric). }
\end{array} \\
T=\quad \text { list of all field operational electric and steel tapes } \\
\text { is maintained within each of the DWSC offices, and paper } \\
\text { records are maintained as a backup in the DWSC groundwater } \\
\text { cabinet. Additionally, for all electronic tapes, a calibration } \\
\text { correction sheet is kept with the equipment at all times and is } \\
\text { located on the electronic tape transportation boxes. }
\end{gathered}
$$

\section{Field Files for Observation Wells}

Maintaining groundwater data and related information in a systematic and organized manner increases the efficiency and effectiveness of data-analysis and data-dissemination efforts. Organization of files, printed and electronic, reduces the likelihood of misplaced information; misplaced data and field notes can lead to analyses based on inadequate information, with a possible decrease in the quality of analytical results.

Each observation well contains a separate set of file folders that is continuously maintained. These folders are identified by county and station number and are permanently filed and archived in the five office locations (Rapid City, Pierre, and Huron, South Dakota; and Bismarck and Grand Forks, North Dakota). For time-series records, the following folders should be in place:

1. Analysis period folder (electronic).-These folders should contain, but are not limited to, such items as NWIS Time Series Data Reports, recent field note sheets, original electronic file, the most current DWSC station analysis, and the AQUARIUS station analysis. This folder should contain all documents related to the working up of the data for the analysis period. Historical paper records of wells could be scanned and digitally archived in each of the corresponding site folders. Electronic records and documentation should be kept using electronic forms (SiteVisit Mobile AQUARIUSSVMAQ).

2. Permanent folder (electronic).--Permanent electronic records should contain photographs of the observation well, and any station documents unrelated to the water year record computation, such as access agreements and installation agreements. The original documents will be stored with the water year during which they were generated. Files are to be organized by site number and archived in the Center's data and project directories. 
It is the responsibility of each field office to maintain the files in proper order. Original data, once filed, should not be removed from the office. For time-series stations, a field folder should contain the station description, a site visit log, and any other information necessary to maintain the observation well. The field folders are to be kept either as paper or electronic records for each of the wells and will be kept on the DWSC servers; where applicable, a copy will be put in select well houses. Paper files for discontinued groundwater sites are scanned, electronic records are archived, and any physical files are sent to an appropriate national archive facility.

\section{Data Processing, Review, and Storage}

This section describes the procedures used for data processing, review, and storage. After groundwater data are collected, they are processed and verified using one or more procedures, such as hydrographic comparison to other wells and review of field notes, and then are stored in an electronic database. Descriptive information on data-collection sites, such as well construction data and location, also should be stored. A more detailed description of the data processing is in appendix 3 .

In general, groundwater data are most accessible and useful to DWSC employees, as well as to those outside the DWSC office, if they are stored in a publicly available computerized database. Storage in a single database also enables interpretations to be more easily verified and repeated. All groundwater data collected by basic data programs and DWSC projects must be stored in the USGS NWIS (technical memorandum 93.03; appendix 1) if the data are amenable. In addition, "all data collected by others - such as cooperators, universities, or consultants - that are used to support published USGS documents and not published or archived elsewhere, shall be placed in NWIS" (Hubbard, 1992, p. 2). Exceptions to these requirements are spatial data coverages and other data for which appropriate database capabilities do not exist in NWIS. A quality database is maintained by checking database files against original data files to ensure accuracy, performing internal cross-checks of the data in the database to identify anomalous data, and maintaining the original data in paper or electronic archives to ensure integrity. Original data are those data - from automated data-collection sites, laboratories, outside sources, and non-automated field observationsunmodified as collected or received, once put into conventional units (engineering units, generally with a decimal; Hubbard, 1992).

All original data in paper form shall be placed in project or data-collection program electronic files. Paper records should be scanned to preserve the original record and archived on the DWSC server. Paper records, once scanned, can be filed within the local office or shipped to an appropriate National Archive facility. The DWSC has a designated Records Liason/ Archivist to oversee and answer any questions regarding archiving. Additionally, within each section of the Center (data, studies, and support services), archiving of all records follow the internal protocols that the USGS has outlined. The processes outlined are complementary to the National Archives and Records Administration procedures for records archiving, disposition, and retention. Original data in electronic form shall be stored in NWIS. All original data shall be preserved unmodified as collected or received.

Any databases external to NWIS shall be documented in accordance with the "Fundamental Science Practices: Planning and Conducting Data Collection and Research" chapter of the USGS Survey Manual (USGS Policy 502.2; U.S. Geological Survey, 2011). Documentation should include a description of data elements (data dictionary), information about the database table or file structure, copies of customized program code, and information about any algorithms used by the database to calculate results for storage or output. New methods used or developed must be approved and fully documented following the policy outlines in the FSP policy (USGS Policy 502.2). If the database is described in a separate report, the documentation may be referenced by the DWSC data management plan and a copy of the documentation kept with the electronic records. A plan for performing periodic internal checks of groundwater data to identify and correct anomalous data should be included. Data shall be reviewed promptly after any data-processing procedure is completed to ensure that the procedure was correctly applied and that the results are consistent both internally to the dataset and with other data for the same site. Specific policy and procedures for reviewing, approving, and releasing information products are summarized in the "Fundamental Science Practices: Review, Approval, and Release of Information Products" chapter of the USGS Survey Manual (USGS Policy 502.4; U.S. Geological Survey, 2016b). This review shall be performed prior to publication or other dissemination to the general public and prior to the technical review of publications that contain the data or that use the data in interpretations.

\section{Continuous Recording Groundwater Wells}

Continuous groundwater-level data are collected in regular intervals in the form of electronic transmissions by satellite or downloading digital record from a data logger during site visits. Ensuring the accuracy of the groundwaterlevel record is a necessary component of ensuring the accuracy of computed groundwater-level data. Generally, records for each station are assigned to the field person responsible for data collection. The assignments are made typically by the Data Program Field Office Chief. The DWSC policy is to work all records following the guidelines and procedures described in the technical memorandum that clarifies the water mission area policy on continuous records processing of timeseries data (2017.01 and 2010.02; U.S. Geological Survey 2017 e, 2010b) after each field trip; however, that is not always possible and some records are not completed until the entire record is worked at the end of the water year, in which case these sites are tagged to highlight that there is a modification 
to the overall process for continuous records processing. Records are analyzed and approved in each office; however, in some cases, a record review may be exchanged between field offices to ensure there is consistency in the records process throughout the DWSC. The procedures for approving and auditing time-series records for water data as documented by the technical memorandum 2017.03 (U.S. Geological Survey, 2017b) are available in appendix 3.

\section{Groundwater-Level Data}

The accuracy of groundwater-level records depends on the completeness and accuracy of the groundwater-level data. Computation of groundwater-level records includes ensuring the accuracy of the record by comparisons made by use of a reference steel or electric tape. A groundwater-level record is assembled for the period of analysis in as complete a manner as possible. Periods of inaccurate groundwater-level data are identified, then corrected or deleted as appropriate. Groundwater-level data are never estimated. If no data exist, the missing or erroneous data period is left with no data.

Starting with water year 2000, the DWSC policy has been to delete unit values of erroneous groundwater-level data from the NWIS database. A water year is the 12-month period, October 1 through September 30, and is designated by calendar year in which it ends.

\section{Station Analysis}

A complete analysis of data collected, procedures used in processing the data, and the logic upon which the computations were based is documented for each station to provide a basis for review and to serve as a reference if questions arise about the records at some future date (Rantz, 1982). Topics discussed in detail in the station analysis include equipment, groundwater-level record, and groundwater-level corrections and remarks. The station analysis is written by the individual who prepares the initial computation for the water year. The station analysis templates for discrete and continuous data are documented in appendix 3 along with the requirements for the analyst, approver, and groundwater database manager.

The DWSC station analysis is in Records Management System (RMS) and supplemented by remarks in AQUARIUS. These two forms should be used for all station analysis periods for all records computation.

\section{Manuscript and Annual Report}

Historically, when records computation for the water year had been completed and the data collected and analyzed by DWSC personnel had been determined to be correct and finalized, the data for that water year were published (displayed as approved) on NWISWeb and, for continuous data, a manuscript was generated and made available to the public. As of 2014, an annual data report is no longer produced because
NWISWeb is now the on-demand, print-ready water-year summary that is used as the annual data product as described on the annual water data reports USGS website (Annual water data reports).

\section{Analyzed, Approved, and Audited Records}

After groundwater-level records for each station have been analyzed by the assigned technician, all records for the DWSC's sites are approved by the Center Data Chief or designee. The goal of the approval step is to ensure that proper methods were applied throughout the process of obtaining the groundwater-level data and computing the record. The individual responsible for analyzing the record is consulted regarding any changes; it is at the approver's discretion whether they make required updates or return the record to the original analyst. Disputes between analysts and approvers are resolved by the Data Program Field Office Chiefs or Data Chief. The approval process is described in more detail in appendix 3 . The final step in the process is the audit. After data are approved and according to the USGS technical memorandum 2017.03 (U.S. Geological Survey, 2017b), any additional examination of the data will be considered an audit. The audit process, level of audit, and audit outcomes (results) are described in the USGS technical memorandum 2017.03 and further information on the procedures and processing of time-series records is described in the time-series guidance (https://water.usgs.gov/osw/time-series-guidance/).

\section{Specific Topics-Data}

The purpose of this specific data management section is to ensure that data from unique hydrologic experiments, such as aquifer tests and tracer tests, are readily available and that supporting information is organized and accessible for future interpretations.

\section{Documentation of Non-Routine Activities}

When data-collection methods are new, non-routine, or research oriented and involve a high degree of professional judgment or trial-and-error, an active record of the conduct, progress, and results of the data collection shall be maintained in procedure notes. These records shall be prepared and maintained in accordance with the following. The Project Chief shall consult with the DWSC Groundwater Specialist concerning the appropriateness of a non-routine method for planned data collection. Procedure notes should include the names of the individuals performing the work, the date on which the work was performed, and the name of the individual making the entries. After the method development, technicalprocedures notes shall be placed in the project files. The results of the technique developed in the technical-procedure notes should be reviewed by the DWSC Groundwater Specialist or designee to ensure that work is proceeding in a 
technically appropriate and relevant manner. If the technique that has been documented in the procedures notebook becomes a routine procedure for the DWSC, then a technical-procedure document shall be developed.

Components of the technical-procedure note should contain the following information:

1. A cover sheet that indicates the technical procedure, title, author or compiler, effective dates for the procedure, and identification number for any technical-procedure documents superseded by the current technical-procedure document.

2. Purpose of the technical procedure and identification of materials and instruments used to collect data.

3. Quantitative statement of the accuracy of data collected using the procedure and limitations on the use of these data.

4. Statements about the advantages, disadvantages, and assumptions of the procedure.

5. Step-by-step instructions to collect data that would enable an independent, qualified person to repeat the work and produce comparable results.

6. A description of how data collected by using the procedure are recorded and preserved. A description of samples to be collected or used, if applicable.

7. A listing of technical references used to compile the technical-procedure document.

8. Attachments (field forms, operator's manual, diagrams, and other pertinent supporting information).

9. The technical procedure used to collect data shall be indicated on the field form.

\section{Identification and Control of Samples Collected During Well Installation}

During the course of many groundwater investigations, samples of various types of earth materials are collected to supplement field observations or to allow laboratory tests, analyses, and measurements that are not possible to perform in the field. Types of samples taken during well installation and other investigations include rock core, drill cuttings, soil, and outcrop. Because these samples can be critical scientific evidence to support interpretations, samples must be easily identifiable, handled and stored in a controlled manner, and traceable. The relation between samples and the dataset they represent must be maintained.

A unique identifier will be developed that will be placed on each individual sample or sample container using materials and methods that are clearly visible, legible, and durable. The unique identifier, as well as other information that is critical for the intended use of a sample (such as orientation), shall be recorded on field forms and laboratory log books. If a sample is subdivided for analysis, the sample identifier shall be transferred to each part of the sample or its container. A sample-control system will be established to record information pertinent to each set of samples. This may be achieved by maintaining a log book, a set of forms, or other appropriate documentation.

The sample-control system shall contain the following information for each sample: unique project identifier; type of sample and general description; source location specifications $(x, y, z)$; date and time of collection; handling, preservation, transportation, and storage; and storage location. Samplecontrol system documentation shall be placed in the project file.

\section{Winterizing Pressure Head Wells}

Pressure head wells are protected from freezing by charging the well with Isopar ${ }^{\mathrm{TM}} \mathrm{M}$ Fluid. The Isopar ${ }^{\mathrm{TM}} \mathrm{M}$ Fluid is injected into the well in volumes adequate to fill the well casing to below the frost line, which will vary for each well and typically ranging from about 5 to 8 feet below the land surface. The Isopar ${ }^{\mathrm{TM}} \mathrm{M}$ Fluid is installed before freezing temperatures in the fall and then removed in the spring after the last expected freezing temperatures. Reference gage and pressure transducer readings are recorded before and after Isopar ${ }^{\mathrm{TM}} \mathrm{M}$ Fluid installation and the differences noted. These differences are prorated between the installation and removal dates over the winter and applied as a correction to the recorded data while the Isopar ${ }^{\mathrm{TM}} \mathrm{M}$ Fluid is in place. The injection volume of the Isopar ${ }^{\mathrm{TM}} \mathrm{M}$ Fluid is noted for each well so that when the Isopar ${ }^{\mathrm{TM}} \mathrm{M}$ Fluid is recovered, that volume should be extracted from the well through the injection valve at the well head. The intended use of the IsoparTM M Fluid is as a solvent and because of the density of the liquid (lighter than water) and negligible solubility, the Isopar ${ }^{\mathrm{TM}} \mathrm{M}$ Fluid maintains a barrier in flowing wells during periods of freezing temperatures to maintain well integrity from the frost line to the surface. As highlighted in the Material Safety Data Sheet, there are no significant environmental hazards listed for use of Isopar ${ }^{\mathrm{TM}} \mathrm{M}$ Fluid (Material Safety Data Sheet; ExxonMobile, 2018). Any flowing well that is injected with the Isopar ${ }^{\mathrm{TM}} \mathrm{M}$ Fluid, which may be sampled for water quality, is flagged for limited water-quality parameter analysis; that is, no volatile or other heavy molecular weight organic hydrocarbons can be sampled without additional purging and well stabilization.

\section{Well Integrity Tests}

The integrity testing done for all Climate Response Network (CRN) wells must be evaluated on a routine basis in accordance with technical memorandum 2012.01 (U.S. Geological Survey, 2012b) (appendix 1). The USGS has 
implemented a formal procedure to evaluate the well integrity with two methods: field evaluation with data collection and trends analysis. Wells not part of the CRN do not follow the well integrity testing procedures as described in this section; however, if a well is being used for specific study and interpretation, a field evaluation is recommended before the start of the interpretative study as described in the technical memorandum 2012.01.

The field evaluation of the integrity test with data collection consists of three components: (1) checking of the physical conditions of the well installation on each site visit, noting any changes in and around the well; (2) annual total depth measurement of the well, following methods described by Cunningham and Schalk (2011); and (3) periodic hydraulic testing. A periodic hydraulic test is to be conducted when a new well is drilled near the existing well; when the evaluation of the annual hydrograph, inspection of the physical condition, or the total depth check indicate a possible deficiency; and otherwise on a 3-year cycle. The hydraulic test that will be used to evaluate the well integrity will be a single-well "slug test," using a mechanical slug. The methods used in conducting the single-well slug test will follow the recommendations described by Cunningham and Schalk (2011). The well integrity tests should be evaluated using a single-well slug test every 3-5 years if the well characteristics remain stable.

The trends analysis consists of an annual check of groundwater-level fluctuations over time within each CRN well. The purpose of this review is to evaluate any major changes in the groundwater levels over time that may be affected by unnatural stresses, such as pumping a nearby well.

All well integrity field notes, data collected, and trends analysis will be archived in a dedicated area on the DWSC computer server and can be retrieved by the Center Groundwater Specialist by request. If there are any changes to the CRN wells that are observed from the field and trends analysis, a determination is made as to whether the well should be rehabilitated to increase the connection with the aquifer.

\section{Data Analysis}

Analysis of groundwater data includes activities ranging from simple statistical applications to the development and application of complex, numerical models. Quality assurance of data analysis begins with a well-thought-out and detailed work plan that describes methods and approaches of data analyses. Analysis procedures shall be reviewed as part of the proposal and work plan development, and during project reviews as appropriate. The methods by which data, or the results of data analyses, are "interpreted," such as the insight involved in the interpolation of groundwater-level data to produce a potentiometric-surface map or the interpretation of the results of model simulations, cannot be completely documented. However, such interpretations must be appropriately qualified, including descriptions of model limitations and data uncertainty.
Reviews of data-analysis procedures ensure that selected analysis techniques are appropriate for meeting project objectives. Data-analysis techniques are identified, at least preliminarily, during development of the project work plan. During project reviews, data-analysis procedures should be reviewed for suitability in meeting the project's objectives. Data-analysis techniques should be reviewed to ensure that preliminary analyses produce valid results. If modifications to procedures are warranted, these modifications are documented in review comments. At a point when data analysis is complete, the results of intermediate and final data analyses are assembled and reviewed. Original data, data analyses, and data that were collected but not used in analysis, along with reasons for the exclusion, are documented as a part of the project review and placed in the project file. Data-analysis procedures shall be referenced and new data-analysis procedures, including those implemented by software, shall be documented in a report released prior to, or as part of, the report giving the results of that technique. Documentation might include a description of the theoretical basis and computational procedure in sufficient detail to perform the analysis, all data requirements or options for the data-analysis procedure, and comparisons of the technique with known or accepted solutions.

Technical memorandums 2005.02 (U.S. Geological Survey, 2005), 96.04 (U.S. Geological Survey, 1996), and 79.04 (U.S. Geological Survey, 1979) have outlined documentation requirements for data-analysis procedures implemented by software. The results of data analysis shall not be presented at a finer spatial or temporal resolution than supported by the input data. The results shall not be displayed with an accuracy that exceeds the capability of the analysis or the accuracy of the data-collection methods. Interpretations of data analysis shall be appropriately qualified, including descriptions of limitations and data uncertainty. The results of any data analysis shall be reviewed, prior to release, to ensure that the analysis is valid. In addition, all data collected and used will follow the 2013 open data policy (Executive Office of the President, 2013; memorandum M-13-13), in which all water data collected must be released to the general public either through NWIS or as a separate data release following the directive outlined by the USGS FSP for release of scientific data (U.S. Geological Survey, 2018c).

\section{Publications}

Disseminating information to Congress and the general public has been required of the USGS since its creation in the Organic Act of 1875. The report review process ensures the quality of the written report, which is the culmination and final result of the training, planning, data collection, and data analysis. To satisfy national responsibilities and to produce accurate and timely reports, the DWSC shall perform the quality-assurance activities described in this section. All groundwater data collected in USGS data-collection programs and interpretive and research projects shall be published in a 
timely manner. Data that are presented on NWISWeb (U.S. Geological Survey, 2018b) that have been reviewed and approved are available to the general public and can be considered published.

The DWSC Director or Deputy Director in consultation with the Office of Quality Assurance shall approve, in writing, any exceptions to the requirement to publish all data, including data collected under an agreement of confidentiality. Data furnished by sources other than the DWSC may be used for analysis and published if the source of the information approves and if (1) the data have been appropriately qualityassured or (2) the data have not been thoroughly qualityassured but are described in terms of appropriate qualifications and limitations. In either case, the source of the data must be acknowledged. Care should be taken to ensure that data are published with the correct number of significant figures. Reports shall be reviewed and approved according to current USGS and DWSC policies, and all information, including data, will be released following the guidelines outlined in the USGS plan for public access to results of federally funded research at the USGS.

\section{Archiving}

Archiving is the final step in the processes of data collection, analysis, and interpretation. Although the report represents the summary of the current work, data and the interpretation should be available for further analysis. Archiving is the systematic process of storing data and information to protect them from change or loss by providing the necessary security. All studies conducted by the DWSC will be archived at the completion of the study agreement. The archive will be maintained on the DWSC servers as an electronic copy and permissions will be set to read only; in addition, two tapes will be copied and written as a backup archive.

Electronic archiving is the systematic process of removing data from active, online computer storage and preserving it with the capability to recover the data. To quality-assure the archiving process, the following steps shall be performed by the DWSC in accordance with the policy and guidelines for Archival of Surface-Water, Groundwater, and Water-Quality Model Applications (appendix 1; 2015.02; U.S. Geological Survey, 2015):

1. All data shall be archived as specified by current USGS policy.

2. All model-related computer files and appropriate simulation results shall be archived as outlined in the technical memorandums 2016.02, 2015.02, 2010.01, 2009.02, 2009.01, 2006.02, and 87.85 (appendix 1; U.S. Geological Survey, 2016a, 2015, 2010a, 2009b, 2009a, 2006, 1987).
3. All aquifer-test data and results shall be published following FSP and archived as outlined in the technical memorandum 2009.01 (appendix 1; U.S. Geological Survey, 2009a).

4. All borehole and surface geophysical data and results should be archived according to the requirements outlined in the technical memorandums 2018.01, 2010.01, and 2009.02 (appendix 1; U.S. Geological Survey, 2018d, 2010a, 2009b).

An archiving plan for groundwater studies conducted within the DWSC is summarized in appendix 4. The archiving plan documents the archiving process and the location of electronic archives and hardcopy files that are kept in addition to project files.

\section{Summary}

As the Nation's principal earth-science information agency, the U.S. Geological Survey (USGS) is depended upon to collect accurate data and produce factual and impartial interpretive reports. Methods for data collection and analysis that were developed by the USGS have become standard techniques used by numerous Federal, State, and local agencies and by private enterprises. The USGS has implemented a program designed to ensure that all scientific work done by or for USGS Water Science Centers is conducted in accordance with a quality-assurance plan. The implementation of a groundwater quality-assurance plan will enhance groundwater data collected by the USGS by providing for the following: consistency; accountability (to clients, scientific community, and regulatory agencies); comparability (yields results of known quality); traceability (written record of how, who, and when work was performed; training; and equipment); and repeatability (documentation of techniques that lead to the similar results with the same accuracy).

This report is a quality-assurance plan for groundwater activities conducted by the USGS Dakota Water Science Center and is meant to complement quality-assurance plans for surface-water and water-quality activities and similar plans for the Dakota Water Science Center and general project activities throughout the USGS.

\section{Acknowledgments}

The U.S. Geological Survey Dakota Water Science Center groundwater quality-assurance plan was adapted from existing plans developed by the Kansas and Washington Water Science Centers. Special thanks to all the reviewers of this document including Joyce Williamson and Galen Hoogestraat from the Dakota Water Science Center. Additional thanks to Rodney Sheets for his technical oversight and review of this document. 


\section{References Cited}

Brunett, J.O., Barber, N.L., Burns, A.W., Fogelman, R.P., Gillies, D.C., Lidwin, R.A., and Mack, T.J., 1997, A qualityassurance plan for district ground-water activities of the U.S. Geological Survey: U.S. Geological Survey Open-File Report 97-11. [Also available at https://water.usgs.gov/ ogw/pubs/OFR9711/gwqap.pdf.]

Cunningham, W.L., and Schalk, C.W., comps., 2011, Groundwater technical procedures of the U.S. Geological Survey: U.S. Geological Survey Techniques and Methods, book 1, chap. A1, 151 p. [Also available at https://pubs.usgs.gov/ $\mathrm{tm} / 1 \mathrm{a} 1 /$.

Executive Office of the President, 2013, Open Data PolicyManaging information as an asset: Memorandum M-13-13, accessed July 13, 2018, at https://www.whitehouse.gov/ sites/whitehouse.gov/files/omb/memoranda/2013/ m-13-13.pdf.

ExxonMobile, 2018, Safety data sheet-IsoparTM M fluid: accessed July 12, 2018, at http://www.msds.exxonmobil. com/IntApps/psims/psims.aspx.

Green, J.H., 1991, WRD project and report management guide: U.S. Geological Survey Open-File Report 91-224, $152 \mathrm{p}$.

Hubbard, E.F., comp., 1992, Policy recommendations for management and retention of hydrologic data of the U.S. Geological Survey: U.S. Geological Survey Open-File Report 92-56, 32 p.

Kozar, M.D., and Kahle, S.C., 2013, Quality-assurance plan for groundwater activities, U.S. Geological Survey, Washington Water Science Center: U.S. Geological Survey Open-File Report 2013-1151, 88 p. [Also available at http://pubs.usgs.gov/ofr/2013/1151/.]

Rantz, S.E., 1982, Measurements and computation of streamflow-Volumes 1 and 2: U.S. Geological Survey WaterSupply Paper 2175, $631 \mathrm{p}$.

Schroder, L.J., and Shampine, W.J., 1992, Guidelines for preparing a quality assurance plan for district offices of the U.S. Geological Survey: U.S. Geological Survey Open-File Report 92-136, 14 p.

Shampine, W.J., Pope, L.M., and Koterba, M.T., 1992, Integrating quality assurance in project work plans of the U.S. Geological Survey: U.S. Geological Survey Open-File Report 92-162, 12 p.

Stallman, R.W., 1971, Aquifer-test design, observation, and data analysis: U.S. Geological Survey Techniques of WaterResources Investigations, book 3, chap. B1, 31 p. [Also available at https://pubs.usgs.gov/twri/twri3-b1/.]
U.S. Geological Survey, 1979, Quality control-Documentation of computer programs used for aquifer modeling: U.S. Geological Survey Ground Water Branch technical memorandum no. 79.04, accessed July 13, 2018, at https://water.usgs.gov/admin/memo/GW/gw79.04.html.

U.S. Geological Survey, 1987, Programs and plans-Policy for the collection and archiving of electronically recorded data: U.S. Geological Survey Water Resources Division memorandum no. 87.85, accessed July 13, 2018, at https://water.usgs.gov/admin/memo/policy/ wrdpolicy87.085.html.

U.S. Geological Survey, 1996, Publications-Policy on documenting the use of ground-water simulation in project reports: U.S. Geological Survey Office of Ground Water technical memorandum no. 96.04, accessed July 13, 2018, at https://water.usgs.gov/admin/memo/GW/gw96.04.html.

U.S. Geological Survey, 2000, Programs and plans-Establishment of a national policy to archive borehole-geophysical logs: U.S. Geological Survey Office of Ground Water technical memorandum 00.03, accessed July 13, 2018, at https://water.usgs.gov/admin/memo/GW/gw00.03.html.

U.S. Geological Survey, 2001, Occupational safety and health program requirements handbook: U.S. Geological Survey Survey Manual SM 444-2-H, accessed July 13, 2018, at https://www2.usgs.gov/usgs-manual/handbook/hb/ 445-2-h.html.

U.S. Geological Survey, 2005, Publications-Policy on documenting the results of new simulations using previously published ground-water models: U.S. Geological Survey Office of Ground Water technical memorandum no. 2005.02, accessed July 13, 2018, at https://water.usgs.gov/ admin/memo/GW/gw05.02.html.

U.S. Geological Survey, 2006, Policy and archive guidance for ground-water data collection using handheld computers: U.S. Geological Survey Office of Ground Water technical memorandum 2006.02, accessed July 13, 2018, at https://water.usgs.gov/admin/memo/GW/gw06.02.html.

U.S. Geological Survey, 2009a, Update on guidance for the preparation, approval, and archiving of aquifer-test results: U.S. Geological Survey Office of Ground Water technical memorandum 2009.01, accessed July 13, 2018, at https://water.usgs.gov/admin/memo/GW/gw09.01.html.

U.S. Geological Survey, 2009b, Establishment of a national policy to archive surface-geophysical data: U.S. Geological Survey Office of Ground Water technical memorandum 2009.02, accessed July 13, 2018, at https://water.usgs.gov/ $\mathrm{admin} / \mathrm{memo} / \mathrm{GW} / \mathrm{gw} 09.02 . \mathrm{html}$. 
U.S. Geological Survey, 2010a, Programs and plans-Update of the national policy to archive borehole-geophysical logs: U.S. Geological Survey Office of Groundwater technical memorandum 2010.01, accessed July 13, 2018, at https://water.usgs.gov/admin/memo/GW/gw10.01.html.

U.S. Geological Survey, 2010b, Continuous records processing of all water time series data: U.S. Geological Survey WRD policy numbered memorandum no. 2010.02, accessed July 13, 2018, at https://water.usgs.gov/admin/memo/policy/ wrdpolicy 10.02.html.

U.S. Geological Survey, 2011, Survey Manual 502.2-Fundamental Science Practices-Planning and conducting data collection and research: U. S. Geological Survey Office of Science Quality and Integrity Survey Manual chapter 502.2, accessed July 13, 2018, at https://www2.usgs.gov/ usgs-manual/500/502-2.html.

U.S. Geological Survey, 2012a, Programs and plans-Guidelines for preparation, submission, and approval of Water Science Center project proposals: U.S. Geological Survey Water Mission Area memorandum no. 13.01, accessed July 13, 2018, at https://water.usgs.gov/admin/memo/policy/ wmapolicy13.01.pdf.

U.S. Geological Survey, 2012b, Policy for evaluation of well integrity for water-level measurements - Initial application to CBR network wells and test phase for all wells: U.S. Geological Survey Office of Groundwater technical memorandum 2012.01, accessed July 13, 2018, at https://water.usgs.gov/admin/memo/GW/gw12.01.html.

U.S. Geological Survey, 2014, Update of policies on storage, review, and publication of discrete groundwater-level data: U.S. Geological Survey Office of Groundwater technical memorandum 2015.01, accessed July 13, 2018, at https://water.usgs.gov/admin/memo/GW/gw2015.01.pdf.

U.S. Geological Survey, 2015, Policy and guidelines for archival of surface-water, groundwater, and water-quality model applications: U.S. Geological Survey Office of Groundwater technical memorandum 2015.02, accessed July 13, 2018, at https://water.usgs.gov/admin/memo/GW/gw2015.02.pdf.

U.S. Geological Survey, 2016a, Policy for documenting, archiving, and public release of numerical groundwater flow and transport models: U.S. Geological Survey Office of Groundwater technical memorandum 2016.02, accessed July 13, 2018, at https://water.usgs.gov/admin/memo/GW/ gw2016.02.pdf.

U.S. Geological Survey, 2016b, Survey Manual 502.4-Fundamental Science Practices-Review, approval, and release of information products: U.S. Geological Survey Office of Science Quality and Integrity Survey Manual Chapter 502.4, accessed July 13, 2018, at https://www2.usgs.gov/ usgs-manual/500/502-4.html.
U.S. Geological Survey, 2017a, Survey Manual 502.9-Fundamental Science Practices-Preservation requirements for digital scientific data: U.S. Geological Survey Office of Science Quality and Integrity Survey Manual Chapter 502.9, accessed July 13, 2018, at https://www2.usgs.gov/ usgs-manual/500/502-9.html.

U.S. Geological Survey, 2017b, Procedures for processing, approving, publishing, and auditing time-series records for water data: U.S. Geological Survey Office of Groundwater technical memorandum 2017.03, accessed July 13, 2018, at https://water.usgs.gov/admin/memo/GW/gw2017.03.pdf.

U.S. Geological Survey, 2017c, Policy and procedures for processing and publishing discrete groundwater-level records: U.S. Geological Survey Office of Groundwater technical memorandum 2017.04, accessed July 13, 2018, at https://water.usgs.gov/admin/memo/GW/gw2017.04.pdf.

U.S. Geological Survey, 2017d, Groundwater technical note 2017.09-Status of USGS groundwater tape calibration program: accessed July 13, 2018, at https://water.usgs.gov/ usgs/ogw/gwtn/2017.09.pdf.

U.S. Geological Survey, 2017e, Clarification of Water Mission Area policy on continuous records processing of time series data - Categorization of groundwater, surface water, and water-quality sites/records: U.S. Geological Survey Office of Groundwater technical memorandum 2017.01, accessed July 13, 2018, at https://water.usgs.gov/admin/memo/GW/ gw2017.01.pdf.

U.S. Geological Survey, 2017f, Procedures for identifying and documenting revisions to USGS water data: U.S. Geological Survey Office of Groundwater technical memorandum 2017.02, accessed July 13, 2018, at https://water.usgs.gov/ admin/memo/GW/gw2017.02.pdf.

U.S. Geological Survey, 2017g, Survey Manual 502.8-Fundamental Science Practices - Review and approval of scientific data for release: U. S. Geological Survey Office of Science Quality and Integrity Survey Manual chapter 502.8, accessed July 13, 2018, at https://www2.usgs.gov/ usgs-manual/500/502-8.html.

U.S. Geological Survey, 2018a, USGS data management plan: U.S. Geological Survey, accessed May 22, 2018, at https://www2.usgs.gov/datamanagement/plan/dmplans.php.

U.S. Geological Survey, 2018b, USGS water data for the Nation: U.S. Geological Survey National Water Information System database, accessed July 12, 2018, at https://doi.org/10.5066/F7P55KJN.

U.S. Geological Survey, 2018c, Fundamental Science Practices (FSP) - FSP FAQs - Release of scientific data: accessed July 13, 2018, at https://www2.usgs.gov/fsp/ faqs_datarelease.asp. 
U.S. Geological Survey, 2018d, Update of the national policy to archive borehole-geophysical logs: U.S. Geological Survey Water Mission Area policy memorandum no. 2018.01, accessed July 13, 2018, at http://logarchiver.usgs.gov/

Resources/Policy\%20Memo.pdf. 
Appendixes 


\section{Appendix 1. Groundwater Technical Memorandums, Groundwater Technical Notes, Water Resources Policies, and the U.S. Geological Survey Survey Manual}

A complete list of groundwater technical memorandums is available at https://water.usgs.gov/admin/memo/GW/.

A complete list of the Groundwater Technical Notes is available at https://water.usgs.gov/usgs/ogw/gwtn/.

A complete list of the Water Resources Policy Memorandums is available at https://water.usgs.gov/admin/memo/policy/policy.html.

The U.S. Geological Survey Manual with a complete list of U.S. Geological Survey policies and procedures can be accessed at https://www2.usgs.gov/usgs-manual/. 


\section{Appendix 2. Groundwater Site Inventory (GWSI) Coding Forms}

1. Groundwater coding form-General site data (9-1904-A version 5.2—Revised March 2015).

2. Groundwater coding form-General spring data (9-1904-B version 5.2-Revised March 2015). 
FORM NO. 9-1904-A
Revised March 2015, NWIS 5.2

Coded by

Checked by

Entered by
File Code

Date

\section{U.S. DEPT. OF THE INTERIOR GEOLOGICAL SURVEY WATER RESOURCES DIVISION \\ GROUNDWATER SITE SCHEDULE General Site Data} $\underset{(\mathrm{C} 5)}{\text { PROJECT }}$\begin{tabular}{|l|l|l|l|l|l|l|}
\hline &
\end{tabular}

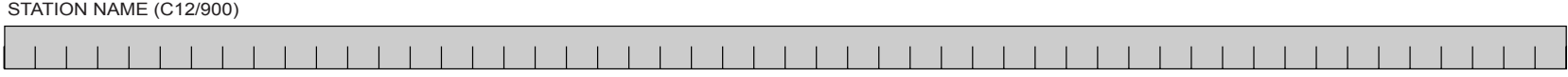

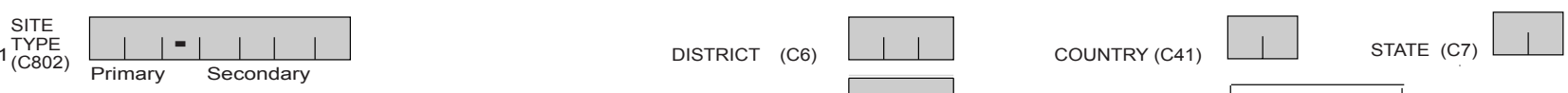
COUNTY or TOWN (C8)

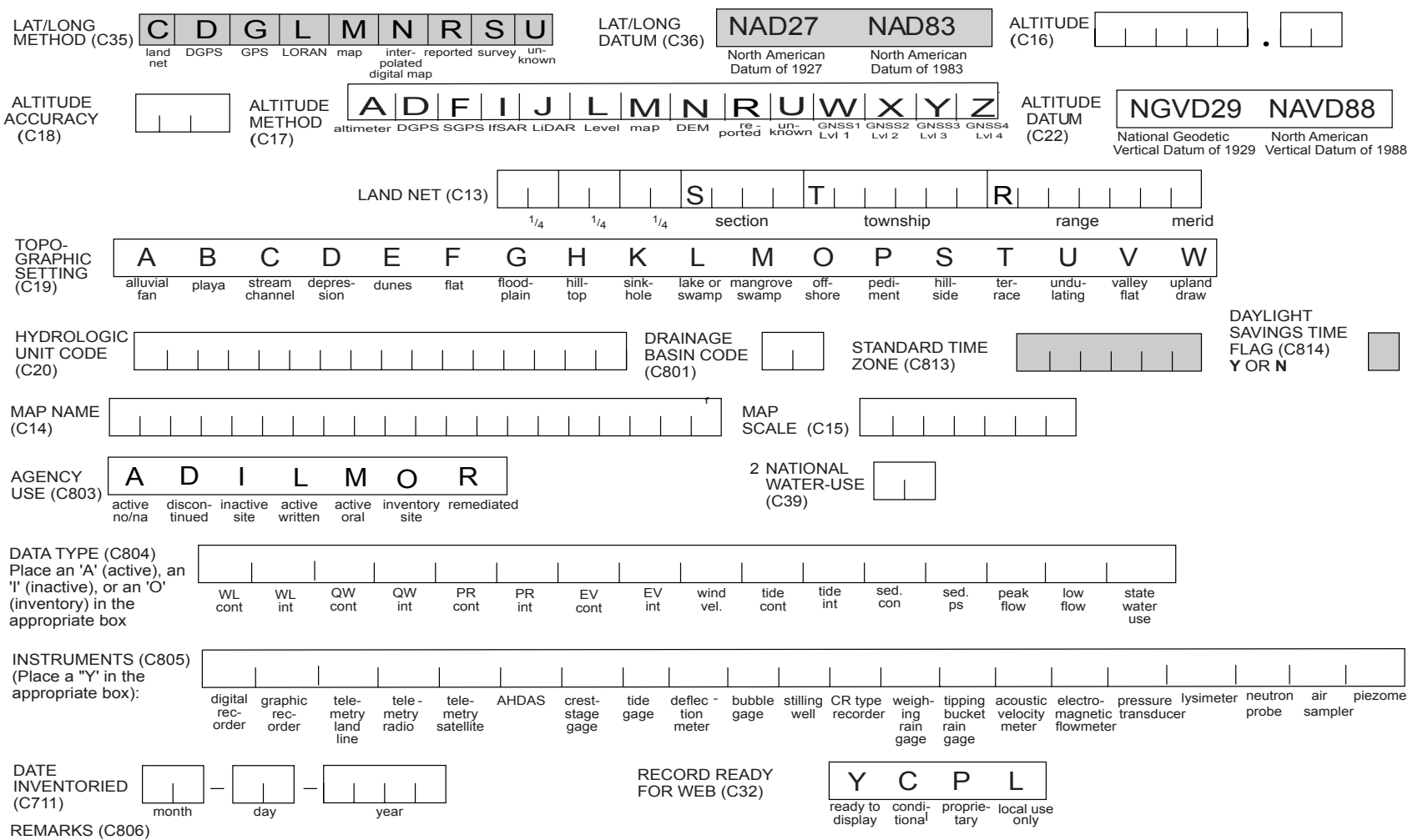


FORM NO. 9-1904-B

Revised March 2015, NWIS 5.2

Coded by

Checked by

Entered by
File Code

Date

\section{U.S. DEPT. OF THE INTERIOR} GEOLOGICAL SURVEY WATER RESOURCES DIVISION

GROUNDWATER SITE SCHEDULE General Spring Data

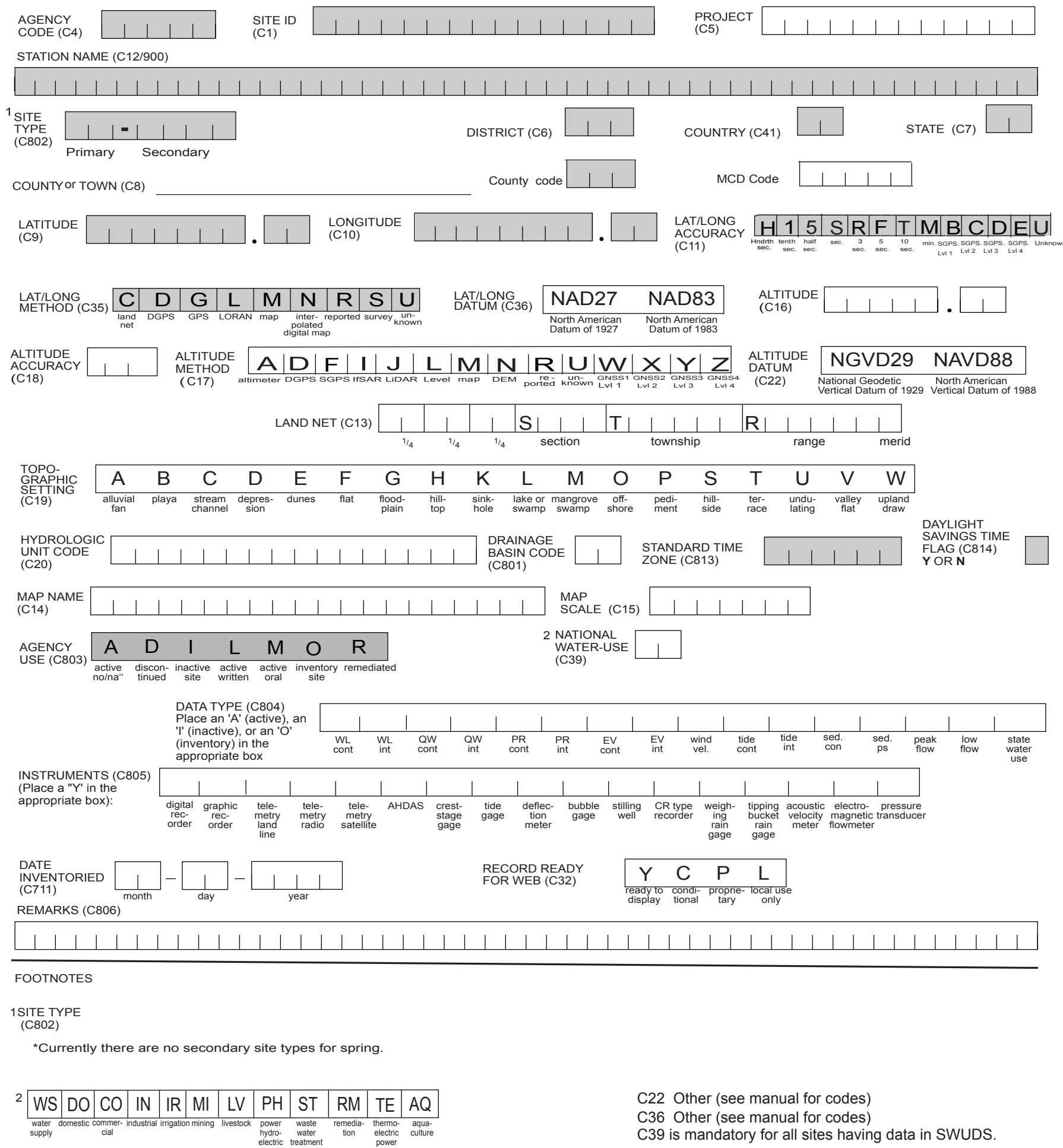




\section{Appendix 3. Documentation of Field Procedures}

\section{Field Procedures}

The purpose of this section is to ensure that field procedures are clearly documented. This section documents processes that should be followed for non-recording groundwater wells and continuous recording groundwater wells.

\section{Non-Recording Groundwater Wells}

Water levels at non-recording wells in the Dakota Water Science Center (DWSC) should be obtained using the following guidelines and procedures from Cunningham and Schalk (2011):

1. Every well should have a permanent measuring point (MP) at a known distance above or below the land-surface datum (LSD). Procedures for establishing an MP are documented at the following:

a. GWPD 3-Establishing a permanent measuring point and other reference marks. Video demonstration at Establishing a Permanent Measuring Point and Reference Marks at a Well.

2. A graduated steel tape is the primary method for obtaining water level from a known MP. An electric tape may be used with supervisor approval for rapidly changing wells and (or) deep wells. Procedures for using a steel or electric tape to determine water level are documented at the following:

a. GWPD 1-Measuring water levels by use of a graduated steel tape. Video demonstration at Measuring Groundwater with Steel Tape.

b. GWPD 4-Measuring water levels by use of an electric tape. Video demonstration at Measuring Groundwater with Electric Tape.

3. In some instances, it may be necessary to measure water levels in a flowing well. Procedures for measuring water level in a flowing well are documented at the following:

a. GWPD 12-Measuring water levels in a flowing well. Video demonstration at Measuring Water Levels in a Flowing Well.

4. All groundwater-level measurements at non-recording wells are required to be measured twice. If the second measurement does not agree with the original measurement within 0.02 foot, continue to make measurements until the reason for lack of agreement is determined or the results are shown to be reliable.
5. The SiteVisit Mobile AQUARIUS (SVMAQ) electronic field form should be used to record the readings and any other pertinent well information.

\section{Continuous Recording Groundwater Wells}

Water levels at continuously recording wells in the

DWSC should be obtained using the following guidelines and procedures:

1. Retrieve the internal log of the data-collection platform (DCP) using instrument or data logger software.

2. Document the current water level recorded by the sensor (not the most recent water level recorded by the data logger).

3. Measure the depth to water in the well using the same methods discussed for non-recording groundwater wells to obtain an accurate water level measurement with which to check the recorder water level (calibration measurement).

4. Inspect the equipment to confirm that installation is operating properly. Recorders that differ from tapedowns by more than twice the accuracy of the equipment need to be reset after a thorough investigation of potential problems.

5. If installed, float and tape should be inspected to ensure that the recorder is functioning properly and correctly. Test the movement of the float wheel by carefully rotating it several inches and releasing it. The tape/recorder should return to the same value. If it does not return to within 0.01 foot of the initial value, then inspect the float tape/ wire, float, and counterweight and rebalance as necessary.

6. The desiccant for submersible pressure sensors, if applicable, needs to be checked on every visit and replaced as needed.

7. Recorder batteries should be checked and replaced as needed and noted on the field sheet.

8. Record the groundwater-level measurements and any other pertinent information in the SVMAQ electronic field form. 


\section{Approval Procedures}

The purpose of this section is to ensure that the approval process is clearly documented. The approval procedures are documented for discrete groundwater-level data and for continuous recoding groundwater wells.

\section{Discrete Groundwater-Level Data}

Policy on storage, review, and publication of discrete groundwater-level data is available in the Water Resources Division Policy Memo 2010.02 (U.S. Geological Survey, 2010), and U.S. Geological Survey (USGS) Policy Memos 2015.01 (U.S. Geological Survey, 2014), and 2017.04 (U.S. Geological Survey, 2017a). The scope of this policy includes discrete groundwater-level measurements collected and stored in the National Water Information System (NWIS) for all USGS programs and projects regardless of data source (for example, USGS collected or furnished data).

1. Discrete groundwater-level data are collected and recorded in the field using electronic field forms. As of the writing of this document (2018), the recommend software is SVMAQ.

2. SVMAQ files are archived on the server in the Field_Visit folder of the appropriate station as outlined in the current DWSC archival structure.

a. Any ancillary information collected, such as pictures, driller logs, and integrity tests, are also filed in their appropriate folders under the current DWSC archival structure.

3. The zipped folder with the SVMAQ file and all ancillary data is imported into the AQUARIUS Field Data Editor (FDE) using the "Landing Pad" in the Visits tab of AQUARIUS Springboard.

4. The SVMAQ file only is also put into the GWvisitDepot for the appropriate office for which the groundwater data were collected. A script automatically runs at night to push those files into the GWSI database. The path for the GWvisitDepot is

a. ISVMAQ $\backslash X X X \backslash G W S I$ processing $\backslash G W v i s i t D e p o t$ where XXX equals the office abbreviation (GFS - Grand Forks; BMK - Bismarck; HSO - Huron; PIR - Pierre; and RDO - Rapid City).

5. On the first of every month, the groundwater Database Administrator will run the groundwater R-script and place script files in the center computer directory as requested by the DWSC Data Chief. The groundwater Database Administrator will send an email notifying project and data staff (as needed) that the R-script has been run and the output is ready to be analyzed.

6. The record "analyst," project or data staff, will complete the analysis steps documented in Process of Analyzing,
Approving and Auditing of Discrete Groundwater-Level Records. The R-script output will be used in the analysis to review the new and historic data.

7. The analyst must complete a station analysis in Records Management System (RMS). All discrete groundwater stations in RMS are assigned a station analysis template. Guidance for completion of the template is available at Station Analysis Template: Discrete-Only GroundwaterLevel Sites. Synoptic network sites measured once annually or less often do not require a station analysis when there is an interpretive product documenting the evaluation of the groundwater-level measurements.

8. The record "approver," project or data staff, must be someone other than the data analyst. The record approver performs a quality-control check of the methods and procedures used to collect and process the record and verifies the accuracy and interpretations of the analyzed period. The approver will complete the approval steps documented in Process of Analyzing, Approving and Auditing of Discrete Groundwater-Level Records. The record approver documents this examination in RMS using the established Approval Guidance: Discrete-only Groundwater Level Sites.

9. Upon approval of the record, the groundwater Database Administrator will set the GWSI data flag to "R" for "Reviewed and Accepted, approved" and will flag questionable or erroneous data with a "Q" for "Rejected." When the groundwater Database Administrator is not the approver, an email will be necessary to inform the groundwater Database Administrator that the data are ready for approval in GWSI.

10. All review processes should be completed in a timely manner consistent with USGS continuous records processing timelines documented in USGS Policy Memo 2010.02 (U.S. Geological Survey, 2010). In general, this means in less than 150 days.

11. Routine audits are not required for discrete groundwaterlevel records. Non-routine audits occur anytime an aspect of an approved record is re-examined. Non-routine audits do not have any required tasks aside from documentation of the audit to include the date of the audit, the auditor, what was examined, why it was examined, and the outcome of the audit to include a discussion of potential revisions, if any. Any revisions to the data will be made following the guidance in USGS Technical Memorandum 2017.02 (U.S. Geological Survey, 2017b).

12. No discrete groundwater-level data stored in NWIS may be published unless they have been processed following these procedures. When followed, this policy meets the requirements of the USGS Fundamental Science Practices for review and release of scientific data on the NWIS Web Interface (NWISWeb) as described in Survey Manual (SM) chapter 502.8 (U.S. Geological Survey, 2017c). 


\section{Continuous Recording Groundwater Wells (AQUARIUS)}

Discrete calibration measurements collected during a continuous or real-time site visit must be processed, reviewed, and approved in the same manner as records from discreteonly sites, but the calibration measurements can be managed with the times-series records as described in USGS Policy Memo 2017.03 (U.S. Geological Survey, 2017d).

1. The record "analyst," project or data staff, will complete the analysis steps documented in Groundwater-Level Records: Process of Analyzing, Approving and Auditing of Groundwater-Level Records.

2. Groundwater-level corrections should be made using the USGS multi-point correction only. Set 2 should be used for all "normal" priority recorder corrections.

3. Do not overcorrect the continuous data. No correction is needed if the time-series data falls within plus or minus $( \pm$ ) the uncertainty of the primary reference reading, unless a correction trend has been established. For example, if the time-series value is 2.00 feet and the primary reference reading is 2.02 feet \pm 0.02 feet, then no correction is needed unless a series of visits has established that the +0.02 feet correction is consistent.

4. The analyst must complete a station analysis in RMS. All continuous groundwater stations in RMS are assigned a station analysis template. Guidance for completion of the template is available at Station Analysis Template: Continuous Groundwater-Level Sites.

5. The record "approver," project or data staff, must be someone other than the data analyst. The record approver performs a quality-control check of the methods and procedures used to collect and process the record and verifies the accuracy and interpretations of the analyzed period. The approver will complete the approval steps documented in Station Analysis Template: Continuous Groundwater-Level Sites. The record approver documents this examination in RMS using the established Approval Guidance: Continuous Groundwater-Level Records.

6. It is the responsibility of the approver to set the data to approved upon resolution of all identified problems. Approved data are labeled as such in RMS, shown in GWSI as "Reviewed and Accepted, approved," displayed on NWISWeb as "Approved," and are considered "published."

7. All review processes should be completed in a timely manner consistent with USGS continuous records processing timelines documented in USGS Policy Memorandum 2010.02. In general, this means in less than 150 days.

8. Routine audits will be made to verify the effectiveness of the approval process. No less than 10 percent of records should receive a routine audit annually. Audits will be tracked in RMS and follow the guidance provided in USGS Policy Memo 2017.03 (U.S. Geological Survey, 2017d). Any revisions to the data will be made following the guidance in USGS Technical Memorandum 2017.02 (U.S. Geological Survey, 2017b).

9. No continuous groundwater-level data stored in NWIS may be published unless they have been processed following these procedures. When followed, this policy meets the requirements of the USGS Fundamental Science Practices for review and release of scientific data on the NWISWeb as described in SM chapter 502.8 (U.S. Geological Survey, 2017c).

\section{References Cited}

Cunningham, W.L., and Schalk, C.W., comps., 2011, Groundwater technical procedures of the U.S. Geological Survey: U.S. Geological Survey Techniques and Methods, book 1, chap. A1, 151 p. [Also available at https://pubs.usgs.gov/tm/1a1/.]

U.S. Geological Survey, 2010, Continuous records processing of all water time series data: U.S. Geological Survey WRD policy numbered memorandum no. 2010.02, accessed July 13, 2018, at https://water.usgs.gov/admin/memo/policy/wrdpolicy 10.02.html.

U.S. Geological Survey, 2014, Update of policies on storage, review, and publication of discrete groundwater-level data: U.S. Geological Survey Office of Groundwater technical memorandum 2015.01, accessed July 13, 2018, at https:// water.usgs.gov/admin/memo/GW/gw2015.01.pdf.

U.S. Geological Survey, 2017a, Policy and procedures for processing and publishing discrete groundwaterlevel records: U.S. Geological Survey Office of Groundwater technical memorandum 2017.04, accessed July 13, 2018, at https://water.usgs.gov/admin/ memo/GW/gw2017.04.pdf.

U.S. Geological Survey, 2017b, Procedures for identifying and documenting revisions to USGS water data: U.S. Geological Survey Office of Groundwater technical memorandum 2017.02, accessed July 13, 2018, at https://water.usgs.gov/admin/memo/GW/gw2017.02.pdf.

U.S. Geological Survey, 2017c, Survey Manual 502.8-Fundamental Science Practices-Review and approval of scientific data for release: U. S. Geological Survey Office of Science Quality and Integrity Survey Manual chapter 502.8, accessed July 13, 2018, at https://www2.usgs.gov/usgsmanual/500/502-8.html.

U.S. Geological Survey, 2017d, Procedures for processing, approving, publishing, and auditing time-series records for water data: U.S. Geological Survey Office of Groundwater technical memorandum 2017.03, accessed July 13, 2018, at https://water.usgs.gov/admin/memo/GW/gw2017.03.pdf. 


\section{Appendix 4. Dakota Water Science Center Groundwater Archive Plan}

The Dakota Water Science Center (DWSC) groundwater archive plan documents the guidelines and procedures used by the Center for archiving groundwater models, aquifer tests, surface geophysical data, and other types of data. The plan serves as a guide for all DWSC personnel involved in groundwater activities. This plan includes topics that the DWSC is involved in and additional categories may be added as needed.

Groundwater technical memorandums for the U.S. Geological Survey (USGS) for topic areas that are not described below are available at http://water.usgs.gov/admin/memo/ $\mathrm{GW} /$.

\section{Groundwater Flow and Transport Models}

Groundwater-flow and transport models are archived following the guidelines established by the USGS technical memorandum 2016.02 (U.S. Geological Survey, 2016). The primary purpose of this memorandum is to update the policy for model archival. When the model archive directory is completed, a request is made to the Groundwater Specialist to place the information in the model archive for the DSWC. All reports that contain groundwater flow and transport models must have their model archive reviewed according to the USGS technical memorandum 2015.02 (U.S. Geological Survey, 2015), where all groundwater model archives are approved by the Office of Quality Assurance, specifically the groundwater liaison within the office. The approvals must be completed through the Office of Quality Assurance before the report is submitted to the Bureau Approving Official for approval. After approval from the groundwater liaison in the Office of Quality Assurance, the model archive subdirectory and accompanying model publication files should be in the DWSC archive when the report is sent to Region for approval. A temporary name can be given to the archive directory; however, the final name should clearly reflect the USGS report number. All groundwater models must be published through a model data release in tandem with the groundwater flow model report.

\section{Aquifer Tests}

Any aquifer test data collected must be published in a data release. In addition, any interpretations that are made from the data must be published as a separate USGS series report or within an interpretive information product that fully describes the test, data, and interpretations.

Aquifer tests are archived following the guidelines established by the USGS technical memorandum 2009.01 (U.S. Geological Survey, 2009a). The information that is suggested for the review of aquifer tests in this memorandum should be included in the archive directory. The name of the subdirectory should include the report number or project location if not included in a report.

\section{Surface Geophysics}

Any surface geophysical data collected must be published in a data release. In addition, any interpretations that are made from the data must be published as a separate USGS series report or within an interpretive information product that fully describes the data collection and interpretations.

Surface geophysical data are archived following the guidelines established by the USGS technical memorandum 2009.02 (U.S. Geological Survey, 2009b). The technical memorandum describes elements to be included in a directory that is added to the storage area. The name of the directory should include a report number or other project identification.

\section{Borehole-Geophysical Logs}

Any borehole-geophysical log data collected must be published in a data release. In addition, any interpretations that are made from the data must be published as a separate USGS series report or within an interpretive information product that fully describes the data collection and interpretations.

Borehole-geophysical logs are archived following the guidelines established by the USGS technical memorandum 2010.01 (U.S. Geological Survey, 2010). This memorandum (1) updates the technical memorandum 2000.03 (U.S. Geological Survey, 2000) and establishes a new requirement that geophysical logs be archived on the USGS Water Science Center's computer database; (2) clarifies archiving of imagelog data, log-type codes, corrections/shifts/post processing, log annotations, and National Water Information System (NWIS) Logs records; and (3) introduces a web-based system to be used for the proper archiving of log data files and headers. Subdirectories for each NWIS 15-digit station number, as previously required, are no longer needed. Each geophysical log file name will include the NWIS 15-digit station number, date of log collection (year month day), two-letter log-type code, and a sequence number. In addition, the file name will include the appropriate extension to indicate it is archived in a format to be used later. The first log of the same type collected on a particular day would have a sequence number of 01 , the second, 02, and so forth. An example path name for an archived is LOGARCHIVE>424531077564201.20000601.MI01.LAS. 


\section{National Water Information System Data}

The NWIS database should be used to store groundwater data when possible. NWIS manuals are available at http://nwis.usgs.gov/currentdocs/index.html. Groundwater System Inventory (GWSI) coding forms are available at http://nwis.usgs.gov/forms/gwforms.html.

\section{Non-NWIS Data}

Non-NWIS data are collected as part of groundwater activities that are not storable in NWIS database. Examples of this kind of data include age dating of water, dye tests, and data from research labs that are not readily stored in NWIS. A storage area for these types of data has been established; however, this area is not intended to duplicate project archives but to ensure that important raw data files, including relevant datacollection information, are readily accessible. If the raw data are compiled in electronic files such as spreadsheets, the data should be organized in a directory with a general descriptive title. A subdirectory can be established by submitting a request to the DWSC Groundwater Specialist. The requesting hydrologist will be responsible for documenting new or experimental methods and describing collection procedures that could be relevant to interpretation of the data. If a hardcopy procedures notebook is necessary for explanation of methods and procedures, an archive hardcopy file is located in the DWSC studies section. Any non-NWIS data that are used to support interpretations in an interpretive product must be published in a USGS data release before or at the same time as the interpretive product is released.

For more information about this publication, contact

Director, USGS Dakota Water Science Center

1608 Mountain View Road

Rapid City, SD 57702

(605) 394-3200

For additional information visit https://www.usgs.gov/centers/dakota-water

Publishing support provided by the

Rolla Publishing Service Center

\section{References Cited}

U.S. Geological Survey, 2000, Programs and plans-Establishment of a national policy to archive borehole-geophysical logs: U.S. Geological Survey Office of Ground Water technical memorandum 00.03, accessed July 13, 2018, at https://water.usgs.gov/admin/memo/GW/gw00.03.html.

U.S. Geological Survey, 2009a, Update on guidance for the preparation, approval, and archiving of aquifer-test results: U.S. Geological Survey Office of Ground Water technical memorandum 2009.01, accessed July 13, 2018, at https://water.usgs.gov/admin/memo/GW/gw09.01.html.

U.S. Geological Survey, 2009b, Establishment of a national policy to archive surface-geophysical data: U.S. Geological Survey Office of Ground Water technical memorandum 2009.02, accessed July 13, 2018, at https://water.usgs.gov/ admin/memo/GW/gw09.02.html.

U.S. Geological Survey, 2010, Programs and plans-Update of the national policy to archive borehole-geophysical logs: U.S. Geological Survey Office of Groundwater technical memorandum 2010.01, accessed July 13, 2018, at https://water.usgs.gov/admin/memo/GW/gw10.01.html.

U.S. Geological Survey, 2015, Policy and guidelines for archival of surface-water, groundwater, and water-quality model applications: U.S. Geological Survey Office of Groundwater technical memorandum 2015.02, accessed July 13, 2018, at https://water.usgs.gov/admin/memo/GW/gw2015.02.pdf.

U.S. Geological Survey, 2016, Policy for documenting, archiving, and public release of numerical groundwater flow and transport models: U.S. Geological Survey Office of Groundwater technical memorandum 2016.02, accessed July 13, 2018, at https://water.usgs.gov/admin/memo/GW/ gw2016.02.pdf. 

